\section{PSIKOLOGI KOMUNIKASI}

EFFY WARDATI MARYAM, S.PSI., M.Si

RAMON ANANDA PARYONTRI, S.PSI, M.PSi

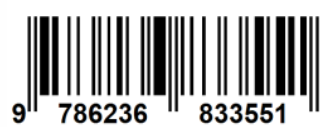

\section{PSIKOLOGI KOMUNIKASI}

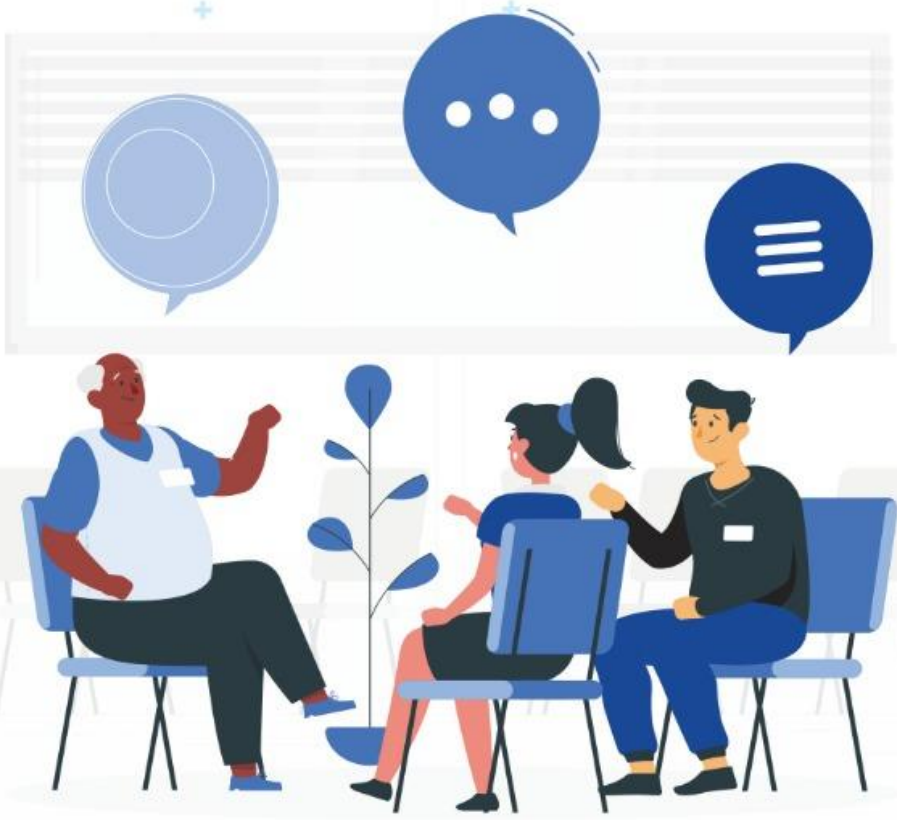

EFFY WARDATI MARYAM, S.PSI., M.Si RAMON ANANDA PARYONTRI, S.PSi, M.PSi 


\section{BUKU AJAR \\ PSIKOLOGI KOMUNIKASI}

Oleh

Effy Wardati Maryam, S.Psi.,M.Si.

Ramon Ananda Paryontri, S.Psi.,M.Psi.

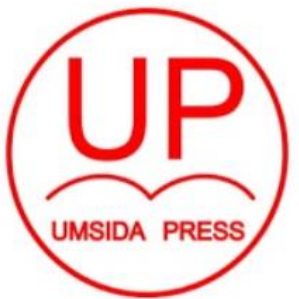

Diterbitkan Oleh: UMSIDA Press

UNIVERSITAS MUHAMMADIYAH SIDOARJO 2020 


\section{BUKU AJAR \\ PSIKOLOGI KOMUNIKASI}

\section{Penulis:}

Effy wardati Maryam, S.Psi.,M.Si.

Ramon Ananda Paryontri, S.Psi.,M.Psi.

\section{ISBN :}

978-623-6833-55-1

\section{Editor:}

Dra. Dwi Nastiti, M.Si.

\section{Design Sampul dan Tata Letak:}

Mochammad Nashrullah, S.Pd.

Yoga Ammy Prajati, S.Kom.

Penerbit:

UMSIDA Press

Anggota IKAPI No. 218/Anggota Luar Biasa/JTI/2019

Anggota APPTI No. 0020181092017

Redaksi

Universitas Muhammadiyah Sidoarjo

Jl. Mojopahit No 666B

Sidoarjo, Jawa Timur

Cetakan Pertama, September 2020

OHak Cipta dilindungi undang undang

Dilarang memperbanyak karya tulis ini dengan sengaja, tanpa ijin tertulis dari penerbit. 


\section{KATA PENGANTAR}

Puji syukur kami panjatkan kehadirat Allah SWT, atas rahmat dan karunia-Nya maka Buku Ajar Psikologi Komunikasi dapat diselesaikan dengan baik. Shalawat dan salam selalu kami sampaikan kepada junjungan Nabi Muhammad SAW.

Tim penulis mengucapkan terimakasih kepada:

1. Dr. Akhtim Wahyuni, M.Ag., Dekan Fakultas Psikologi dan Ilmu Pendidikan yang memberikan arahan dan motivasi kepada penulis dalam menyelesaikan buku ajar ini.

2. Widyastuti,M.Psi.,Psikolog, Ketua Program Studi Psikologi yang telah memberikan dukungan untuk menyusun buku ajar ini.

3. Rekan-rekan dosen pengampu Mata Kuliah Psikologi Komunikasi di Program Studi Psikologi yang telah berbagi pengalaman dalam mengampu mata kuliah tersebut.

Penulis mengharapkan saran dan kritik untuk menyempurnakan buku ajar Psikologi Komunikasi ini. Terimakasih.

Tim Penulis 


\section{DAFTAR ISI}

\section{HALAMAN SAMPUL \\ KATA PENGANTAR \\ DAFTAR ISI}

\section{BAB I PENGERTIAN DAN RUANG LINGKUP}
A. Hubungan Psikologi dan Komunikasi ...........................
B. Pengertian Psikologi Komunikasi...................................4
C. Pendekatan Psikologi terhadap Komunikasi.................4
D. Ruang Lingkup Psikologi Komunikasi.............................5
E. Tujuan Komunikasi.....................................................6
F. Ciri-ciri Pendekatan Psikologi Pada Komunikasi...........6
G. Komunikasi Efektif.................................................... 7

\section{BAB II KARAKTERISTIK MANUSIA KOMUNIKAN}
A. Perspektif Psikologi tentang Manusia Komunikan...12
B. Faktor-faktor yang Mempengaruhi Perilaku Manusia.....

\section{BAB III KOMUNIKASI INTRAPERSONAL}

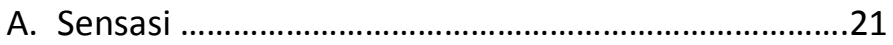

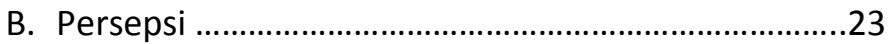

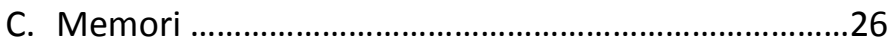

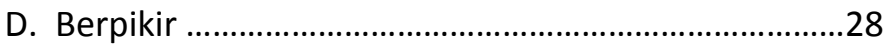

BAB IV KOMUNIKASI INTERPERSONAL
A. Tujuan Komunikasi Interpersonal 32
B. Elemen Komunikasi Interpersonal
C. Faktor-faktor Yang Mempengaruhi Komunikasi Interpersonal

\section{BAB V KOMUNIKASI KELOMPOK}

A. Klasifikasi Kelompok 
B. Kelompok Berdasarkan Perspektif Psikologi

.57

C. Pengaruh Kelompok Terhadap Perilaku

Komunikasi

61

BAB VI KOMUNIKASI MASSA

A. Pengertian Komunikasi Massa .................................69

B. Faktor-faktor Yang mempengaruhi Reaksi

Khalayak Terhadap Komunikasi Massa ....................71

C. Efek Komunikasi Massa .............................................76

BAB VII KOMUNIKASI VERBAL dan NON VERBAL
A. Komunikasi Verbal .82
B. Bahasa .83
C. Komunikasi Non Verbal .86

BAB VIII KOMUNIKASI PERSUASIF
A. Pengertian Komunikasi Persuasif .92
B. Elemen Komunikasi Persuasif .94
C. Faktor Penentu Komunikasi Persuasif .95
D. Ranah Komunikasi Persuasif 101
E. Teknik Komunikasi Persuasif 102

DAFTAR PUSTAKA BIODATA PENULIS 


\section{BATANG TUBUH DAN}

\section{SUB-CAPAIAN PEMBELAJARAN MATA KULIAH}

\begin{tabular}{|c|c|}
\hline BAB & Sub-Capaian Pembelajaran Mata Kuliah \\
\hline $\begin{array}{l}\text { BAB I } \\
\text { Pengertian } \\
\text { dan Ruang } \\
\text { Lingkup } \\
\text { Psikologi } \\
\text { Komunikasi }\end{array}$ & $\begin{array}{l}\text { 1. Mahasiswa mampu menjelaskan konsep Psikologi } \\
\text { Komunikasi } \\
\text { 2. Mahasiswa mampu menjelaskan berbagai } \\
\text { pendekatan psikologis dalam komunikasi } \\
\text { 3. Mahasiswa mampu mendeskripsikan ruang lingkup } \\
\text { Psikologi Komunikasi } \\
\text { 4. Mahasiswa mampu mendeskripsikan tujuan } \\
\text { Komunikasi } \\
\text { 5. Mahasiswa mampu menguraikan ciri-ciri } \\
\text { pendekatan psikologi pada komunikasi } \\
\text { 6. Mahasiswa mampu mendeskripsikan komunikasi } \\
\text { yang efektif menurut perspektif psikologi }\end{array}$ \\
\hline $\begin{array}{l}\text { BAB II } \\
\text { Karakteristik } \\
\text { Manusia } \\
\text { Komunikan }\end{array}$ & $\begin{array}{l}\text { 1. Mahasiswa mampu membandingkan berbagai } \\
\text { perspektif psikologi tentang manusia komunikan } \\
\text { 2. Mahasiswa mampu mendeskripsikan faktor-faktor } \\
\text { yang mempengaruhi perilaku manusia dari perspektif } \\
\text { psikologi }\end{array}$ \\
\hline $\begin{array}{l}\text { BAB III } \\
\text { Komunikasi } \\
\text { Non Verbal }\end{array}$ & $\begin{array}{l}\text { 1. Mahasiswa mampu menjelaskan konsep komunikasi } \\
\text { non verbal } \\
\text { 2. Mahasiswa mampu mendeskripsikan fungsi } \\
\text { komunikasi non verbal } \\
\text { 3. Mahasiswa mampu menguraikan klasifikasi } \\
\text { komunikasi non verbal }\end{array}$ \\
\hline $\begin{array}{l}\text { BAB IV } \\
\text { Komunikasi } \\
\text { Intrapersonal }\end{array}$ & $\begin{array}{l}\text { 1. Mahasiswa mampu menjelaskan konsep komunikasi } \\
\text { intrapersonal } \\
\text { 2. Mahasiswa mampu menguraikan elemen-elemen } \\
\text { dalam komunikasi intrapersonal }\end{array}$ \\
\hline
\end{tabular}




\begin{tabular}{|l|l|}
\hline & $\begin{array}{l}\text { 3. Mahasiswa mampu menguraikan faktor-faktor yang } \\
\text { mempengaruhi komnukasi intrapersonal }\end{array}$ \\
\hline $\begin{array}{l}\text { BAB V } \\
\text { Komunikasi } \\
\text { Interpersonal }\end{array}$ & $\begin{array}{l}\text { 1. Mahasiswa mampu menjelaskan konsep komunikasi } \\
\text { interpersonal }\end{array}$ \\
$\begin{array}{l}\text { 2. Mahasiswa mampu menguraikan elemen-elemen } \\
\text { dalam komunikasi interpersonal }\end{array}$ \\
$\begin{array}{l}\text { BAB VI } \\
\text { Komunikasi } \\
\text { Kelompok }\end{array}$ & $\begin{array}{l}\text { Mahasiswa mampu menguraikan faktor-faktor yang } \\
\text { mempengaruhi komunikasi interpersonal }\end{array}$ \\
\hline $\begin{array}{l}\text { BAB VII } \\
\text { Komunikasi } \\
\text { Massa }\end{array}$ & $\begin{array}{l}\text { 2. Mahasiswa mampu menjelaskan konsep komunikasi } \\
\text { kelompok yang mempengaruhi komunikasi }\end{array}$ \\
\hline $\begin{array}{l}\text { BAB VIII } \\
\text { Komunikasa } \\
\text { Persuasif }\end{array}$ & $\begin{array}{l}\text { 2. Mahasiswa mampu menjelaskan konsep komunikasi } \\
\text { komunikasi massa }\end{array}$ \\
\hline
\end{tabular}




\section{BAB 1 \\ PENGERTIAN dan RUANG LINGKUP PSIKOLOGI KOMUNIKASI}

Capaian Pembelajaran Mata Kuliah meliputi :

a. Aspek Sikap dan Tata Nilai :

(1) Bertakwa kepada Tuhan Yang Maha Esa dan mampu menunjukkan sikap religious

(2) Berkontribusi dalam peningkatan mutu kehidupan bermasyarakat, berbangsa, bernegara, dan kemajuan peradaban berdasarkan Pancasila

(3) Menghargai keanekaragaman budaya, pandangan, agama dan kepercayaan serta pendapat atau temuan orisinal orang lain

b. Aspek Ketrampilan Umum :

(1) Menguasai konsep teoritis hubungan manusia dengan lingkungan sosialnya

(2) Menguasai konsep teoritik komunikasi antar pribadi dan komunikasi massa

c. Aspek Ketrampilan Khusus :

Mampu menerapkan pemikiran logis, kritis, sistematis, dan inovatif dalam konteks pengembangan atau implementasi ilmu pengetahuan dan teknologi yang memperhatikan dan menerapkan nilai humaniora

d. Aspek Penguasaan Pengetahuan :

Mampu memahami dan menjelaskan aspek-aspek psikologi yang berperan dalam komunikasi. 
Bab ini membahas tentang konsep dasar dalam Psikologi Komunikasi yang meliputi berbagai pendekatan atau perspektif psikologi tentang komunikasi, ruang lingkup Psikologi Komunikasi, tujuan komunikasi menurut perspektif psikologi, ciri-ciri pendekatan psikologi terhadap komunikasi, dan komunikasi yang efektif menurut pandangan psikologi.

\section{A. Hubungan Psikologi dan Komunikasi}

Psikologi sebagai ilmu tentang perilaku manusia merupakan salah satu pemeran utama dalam kajian komunikasi. Psikologi menggunakan teori-teori tentang perilaku sebagai pondasi dasar yang menjelaskan bagaimana dan mengapa manusia melakukan komunikasi. Perilaku manusia juga berkaitan erat dengan komunikasi yang dilakukan, baik secara intrapersonal, interpersonal, maupun antar kelompok.

Komunikasi merupakan peristiwa sosial, yaitu peristiwa yang terjadi ketika seorang individu berinteraksi dengan individu lainnya. Analisis terhadap peristiwa sosial secara psikologis, mengarah pada psikologi sosial. Posisi psikologi komunikasi memang cenderung menjadi bagian dari psikologi sosial. Oleh karena itu, pendekatan dalam psikologi komunikasi juga menggunakan pendekatan dalam psikologi sosial. 

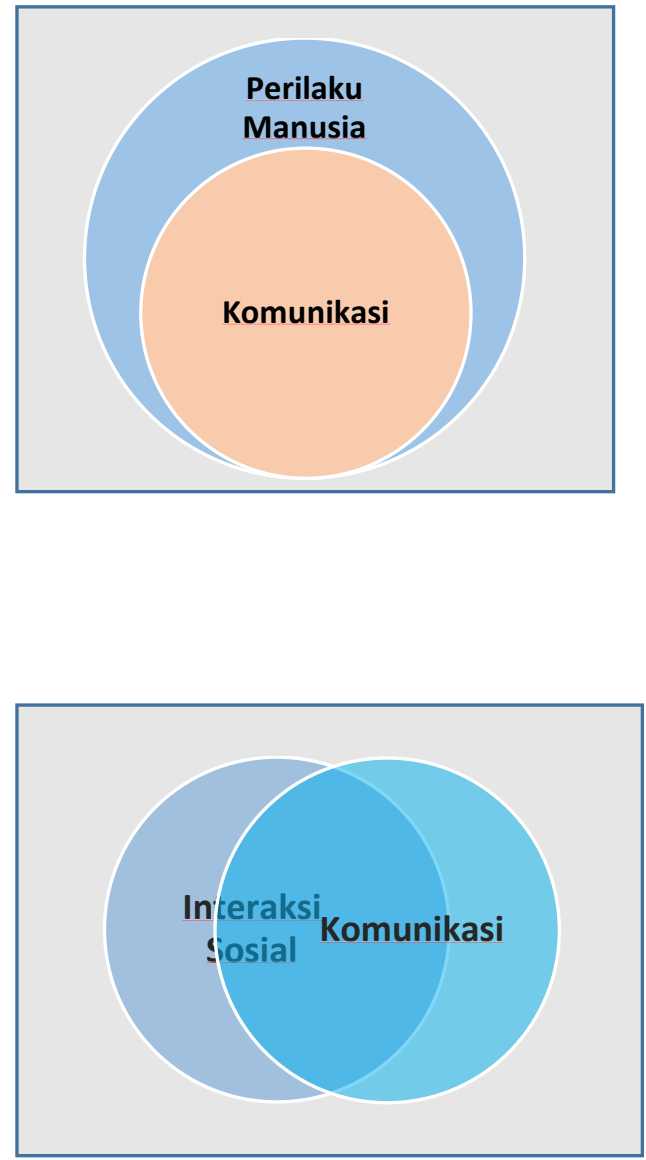


\section{B. Pengertian Psikologi Komunikasi}

Hovland, Janis dan Kelly (1953) yang semuanya sebagai psikolog mendefinisikan komunikasi sebagai "The process by which an individual (the communicator) transmits stimuli (usually verbal) to modify the behavior of other individuals (the audience). Dance mengartikan komunikasi menurut kerangka psikologi behaviorisme sebagai usaha untuk menimbulkan respons melalui lambing-lambang verbal, saat lambang verbal tersebut berperan sebagai stimuli (Rakhmat, 2011).

Psikologi merupakan ilmu yang mempelajari tentang perilaku manusia. Psikologi menempatkan manusia sebagai subjek inti komunikasi yang memerankan peran utama pada proses pertukaran informasi, ide atau konsep yang dipengaruhi oleh faktor lingkungan maupun budaya (Maulana \& Gumelar, 2013). George A. Miller mendefinisikan psikologi sebagai "Psychology is the science that attempts to describe, predict, and control mental and behavioral event."

Dengan demikian, psikologi komunikasi adalah ilmu yang berupaya menguraikan, memprediksi, dan mengendalikan peristiwa mental dan behavioral dalam komunikasi. Menurut Fisher, peristiwa mental merupakan internal mediation of stimuli sebagai akibat berlangsungnya komunikasi. Sedangkan peristiwa behavioral adalah segala hal yang nampak ketika individu berkomunikasi (Rakhmat, 2011).

\section{Pendekatan Psikologi Terhadap Komunikasi}

Psikologi memandang komunikasi sebagai proses penyampaian energi dari alat-alat indera ke otak, saat 
peristiwa penerimaan dan pengolahan informasi, dimana terjadi proses saling mempengaruhi di antara berbagai sistem dalam diri individu dan di antara individu (Rakhmat, 2011). Saat kita membaca buku, retina mata yang terdiri dari 12 juta lebih sel syaraf, bereaksi pada cahaya dan meneruskan pesan pada cabang-cabang syaraf yang menyambungkan mata dengan syaraf optik, lalu syaraf optik meneruskan impulsimpuls syaraf ke otak. 10-14 juta sel syaraf pada otak (neuron) dirangsang oleh berbagai impuls yang datang. Di sinilah terjadi proses persepsi. Psikologi tidak hanya mengulas komunikasi di antara neuron, melainkan juga berupaya menganalisa seluruh komponen yang terlibat dalam proses komunikasi yang mencakup komunikan dan komunikator. Dalam psikologi, komunikasi juga dipahami sebagai proses penyampaian pesan dalam psikoterapi.

\section{Ruang Lingkup Psikologi Komunikasi}

Ruang lingkup Psikologi Komunikasi mencakup halhal sebagai berikut :

1. Proses mental (internal) saat berlangsungnya proses komunikasi, meliputi sensasi, persepsi, memori, dan berpikir (komunikasi dalam diri individu).

2. Komunikan, yaitu setiap peserta komunikasi, bisa komunikator (yang memulai komunikasi) atau komunikate (penerima informasi). Psikologi memberikan karakteristik manusia komunikan, serta faktor-faktor yang mempengaruhi perilaku komunikasinya (faktor internal dan eksternal). 
3. Komunikator. Psikologi berupaya menjelaskan mengapa sebuah sumber komunikasi berhasil mempengaruhi individu lain, sedangkan sumber komunikasi yang lain mengalami kegagalan.

4. Komunikasi antar individu. Psikologi mencoba mencari tahu bagaimana pesan dari seorang individu menjadi stimulus yang menimbulkan respon bagi individu lain.

5. Psikolinguistik : perpaduan ilmu antara psikologi dan linguistik. Psikologi meneliti proses pengungkapan pikiran menjadi lambang, bentuk-bentuk lambang, dan pengaruh lambang terhadap perilaku manusia.

\section{E. Tujuan Komunikasi}

Komunikasi ditujukan untuk memberikan informasi, menghibur, atau mempengaruhi (komunikasi persuasif). Komunikasi persuasif berkaitan erat dengan psikologi. Persuasif diartikan sebagai proses mempenagruhi dan mengendalikan perilaku orang lain melalui pendekatan psikologis (Rakhmat, 2011).

\section{F. Ciri-ciri Pendekatan Psikologi Komunikasi}

Berbagai disiplin ilmu juga mempelajari tentang komunikasi, seperti sosiologi, filsafat, dan psikologi. Lalu, apa yang membedakan atau menjadi ciri khas pendekatan psikologi dengan pendekatan yang lain ? Psikologi meneliti kesadaran dan pengalaman manusia pada perilaku individu komunikan.

Fisher (1978) menguraikan ciri-ciri pendekatan psikologi pada komunikasi sebagai berikut : 
1. Penerimaan stimuli secara inderawi (sensory reception of stimuli). Psikologi melihat komunikasi sejak organ-organ penginderaan menerima stimuli berupa data. Stimuli bisa berbentuk orang, suara, warna, ucapan, dan sebagainya yang mempengaruhi individu.

2. Proses yang mengantarai stimulus dan respon (internal mediation of stimuli). Terjadi pengolahan stimulus dalam "kotak hitam" hingga memunculkan respon. Jika seseorang tersenyum, tertawa, bertepuk tangan, maka ia berada dalam keadaan gembira.

3. Prediksi respon (prediction of response). Psikologi komunikasi melihat bagaimana respon pada masa lalu dapat meramalkan munculnya respon yang akan datang.

4. Peneguhan respon (reinforcement of responses), merupakan respon lingkungan atau orang lain pada respon individu yang asli, atau disebut juga dengan umpan balik (feedback).

\section{G. Komunikasi Efektif}

Kepribadian individu terbentuk sepanjang hidup, sehingga komunikasi pun menjadi hal yang penting untuk pertumbuhan kepribadian. Melalui komunikasi, individu menemukan dirinya, mengembangkan konsep diri, dan mengembangkan interaksi dengan dunia di sekitarnya. Hubungan dengan individu lain akan menentukan kualitas hidup seseorang. Jika orang lain tidak memahami gagasan seorang individu, jika saat berkomunikasi dengan orang lain yang terjadi justru pertentangan pendapat dari orang lain karena tidak memahami maksud pembicaraan, jika semakin 
sering berkomunikasi semakin jauh jarak dengan orang lain, jika individu selalu gagal mendorong individu lain bertindak, maka ini semua bisa dikatakan bahwa terjadi kegagalan dalam komunikasi, atau komunikasi yang tidak efektif (Rakhmat, 2011).

Tanda-tanda komunikasi yang efektif menurut Tubbs dan Moss (1974), minimal menimbulkan lima hal, sebagai berikut :

1. Pengertian : penerimaan secara cermat dari isi stimuli seperti yang dimaksudkan komunikator.

2. Kesenangan : menimbulkan hubungan hangat atau akrab, dan menyenangkan.

3. Mempengaruhi sikap : mampu memunculkan perubahan sikap pada komunikan, yang awalnya tidak suka berubah menjadi menyukai, dan sebaliknya. Perubahan sikap ini bisa dilakukan melalui komunikasi persuasif.

4. Hubungan sosial yang baik. Komunikasi yang dilakukan mampu menciptakan hubungan baik dengan individu lain. Manusia sebagai makhluk sosial tidak bisa menjalani kehidupan sendiri, selalu membutuhkan individu lain. Komunikasi dinilai efektif jika mampu menciptakan hubungan sosial yang baik, bukan malah memunculkan pertentangan atau konflik.

5. Tindakan : merupakan ukuran nyata dari efektivitas sebuah komunikasi. Tidak mudah untuk mempengaruhi individu lain agar melakukan tindakan tertentu sesuai keinginan komunikator. Perubahan perilaku melalui komunikasi ini membutuhkan proses komunikasi yang diawali dengan pengertian, kesenangan, perubahan sikap, 
terciptanya hubungan sosial yang baik, baru kemudian memudahkan terjadinya perubahan tindakan. Perubahan atau munculnya perilaku tertentu ini bisa dilakukan melalui komunikasi persuasif.

\section{RINGKASAN}

1. Psikologi komunikasi merupakan ilmu yang berusaha untuk menguraikan, meramalkan (predict), dan mengendalikan (control) peristiwa mental dan behavioral dalam komunikasi.

2. Ruang lingkup psikologi komunikasi mencakup proses mental (komunikasi intrapersonal), komunikan, komunikator, komunikasi interpersonal, dan psikolinguistik.

3. Tanda-tanda komunikasi yang efektif meliputi adanya pemahaman, kesenangan, perubahan sikap, terciptanya hubungan sosial yang baik, dan perubahan perilaku dari komunikan.

\section{LATIHAN}

1. Psikologi dan komunikasi merupakan dua hal yang sangat berdekatan dan berkaitan. Bagaimana keterkaitan antara kedua bidang tersebut?

2. Psikologi memiliki pendekatan khas dalam memandang terjadinya proses komunikasi. Bagaimanakah psikologi menjelaskan tentang proses komunikasi tersebut? 


\section{DAFTAR PUSTAKA}

Rakhmat, Jalaluddin. 2011. Psikologi Komunikasi, Cetakan Ke-

27. Bandung : Remaja Rosdakarya.

Maulana, Herdiyan dan Gumelar, Gumgum. 2013. Psikologi

Komunikasi dan Persuasi. Jakarta : Akademia Permata.

Hovland, Carl I., Janis, Irving L., Kelley, Harold H. 1953.

Communication and Persuasion : Psychological Studies

of Opinion Change. New Haven : Yale University Press.

Fisher, B.A. 1978. Perspectives on Human Communication. New York : Macmillan Publishing Co.,Inc.

Tubbs, S.L. dan Moss, Sylvia. 1974. Human Communication : An Interpersonal Perspective. New York : Random House. 


\section{BAB 2}

\section{KARAKTERISTIK MANUSIA KOMUNIKAN}

Capaian Pembelajaran Mata Kuliah meliputi :

a. Aspek Sikap dan Tata Nilai :

(1) Bertakwa kepada Tuhan Yang Maha Esa dan mampu menunjukkan sikap religious

(2) Berkontribusi dalam peningkatan mutu kehidupan bermasyarakat, berbangsa, bernegara, dan kemajuan peradaban berdasarkan Pancasila

(3) Menghargai keanekaragaman budaya, pandangan, agama dan kepercayaan serta pendapat atau temuan orisinal orang lain

b. Aspek Ketrampilan Umum :

(1) Menguasai konsep teoritis hubungan manusia dengan lingkungan sosialnya

(2) Menguasai konsep teoritik komunikasi antar pribadi dan komunikasi massa

c. Aspek Ketrampilan Khusus :

Mampu menerapkan pemikiran logis, kritis, sistematis, dan inovatif dalam konteks pengembangan atau implementasi ilmu pengetahuan dan teknologi yang memperhatikan dan menerapkan nilai humaniora

d. Aspek Penguasaan Pengetahuan :

Mampu memahami dan menjelaskan aspek-aspek psikologi yang berperan dalam komunikasi. 
Psikologi memandang bahwa pemeran utama dalam komunikasi adalah manusia sebagai komunikan. Komunikasi ditentukan oleh perilaku manusia komunikan. Psikologi berperan saat membicarakan tentang proses pemrosesan pesan yang diterima manusia. Fokus psikologi komunikasi adalah manusia. Banyak teori dalam ilmu komunikasi yang dilatarbelakangi oleh empat pendekatan psikologi, yaitu psikodinamika, behaviorisme, kognitif, dan humanistik. Bab ini akan membahas konsepsi psikologi tentang manusia berdasarkan empat perspektif tersebut.

\section{A. Konsepsi Manusia menurut Psikologi}

\section{Konsepsi Manusia dalam Psikodinamika}

Pendekatan ini menekankan pada pikiran ketidaksadaran, konflik antara naluri biologis dan tuntutan masyarakat, serta pengalaman keluarga sejak usia dini. Pendekatan ini berpendapat bahwa naluri biologis yang tidak dipelajari, terutama dorongan seksual dan agresif, mempengaruhi cara manusia berpikir, merasa, dan berperilaku. Naluri-naluri ini terpendam dalam alam bawah sadar, seringkali bertentangan dengan tuntutan masyarakat (King, 2012). Menurut Sigmund Freud (pelopor pendekatan psikodinamika), hubungan dini dengan orang tua juga menjadi faktor utama yang membentuk kepribadian manusia, yang selanjutnya menentukan perilaku manusia.

Freud menyampaikan bahwa perilaku manusia merupakan hasil interaksi id, ego, dan superego. Id menyimpan dorongan-dorongan biologis manusia dan sebagai pusat instink (hawa nafsu). Id bekerja berdasarkan prinsip 
kesenangan (pleasure principle) dan menuntut segera memenuhi kebutuhannya. Namun Id tidak mampu memuaskan keinginannya. Ego berfungsi menjembatani tuntutan Id dengan realitas atau rasional, inilah yang menjadi prinsip kerja Ego (reality principle). Ego mendorong manusia berperilaku secara rasional. Ego berada di tengah antara memenuhi tuntutan Id dan peraturan Superego. Unsur moral dalam pertimbangan terakhir perilaku manusia disebut Freud sebagai superego. Superego merupakan hati nurani yang menginternalisasi norma-norma sosial dan kultural masyarakat. Dari pendekatan psikodinamika inilah muncul konsep "manusia berkeinginan" (Homo Volens).

\section{Konsepsi Manusia Menurut Behaviorisme}

Pendekatan behavioristik menekankan pada respon perilaku yg dapat diamati, memusatkan pada interaksi dengan lingkungan yang dapat dilihat dan diukur. Lingkungan merupakan penentu perilaku manusia. Pelopor pendekatan ini adalah John B. Watson dan B.F. Skinner. Skinner meyakini bahwa ganjaran dan hukuman menentukan perilaku manusia.

Seluruh perilaku manusia (kecuali instink) merupakan hasil belajar, yaitu perubahan perilaku sebagai pengaruh lingkungan. Oleh karena itu, pendekatan ini juga disebut teori belajar. Dari behaviorisme inilah muncul konsep "manusia mesin" (Homo Mechanicus).

3. Konsepsi Manusia menurut Pendekatan Kognitif Menurut pendekatan ini, otak manusia mengandung pikiran yang memungkinkan proses-proses mental untuk 
mengingat, merencanakan, menentukan tujuan, mengambil keputusan, dan kreatif. Pendekatan ini menekankan pada proses-proses mental yang terlibat dalam mengetahui (bagaimana manusia mengarahkan perhatian, mempersepsi, mengingat, berpikir, dan memecahkan masalah). Pikiran merupakan sebuah sistem pemecahan masalah yang aktif dan sadar.

Pandangan ini berlawanan dengan pandangan behavioristic yang menekankan bahwa lingkunganlah yang mengendalikan perilaku manusia. Pendekatan kognitif juga bertentangan dengan pandangan psikodinamika yang memandang perilaku manusia dikendalikan oleh naluri atau bagian ketidaksadaran lainnya. Pendekatan kognitif meyakini bahwa proses-proses mental individu merupakan perilaku yang terkendali melalui ingatan, persepsi, citra, dan berpikir (King, 2012). Dari pandangan inilah muncul konsep "manusia berpikir" (Homo Sapiens).

\section{Konsepsi Manusia menurut Pendekatan Humanistik}

Pendekatan ini menekankan pada kualitas-kualitas positif seseorang, kapasitas untuk pertumbuhan positif, dan kebebasan untuk memilih takdir apapun. Menurut Maslow dan Rogers, manusia memiliki kemampuan untuk mengendalikan hidupnya dan menghindar dari manipulasi lingkungan (King, 2012). Manusia dapat memilih hidupnya dengan nilai-nilai kemanusiaan yang lebih tinggi, seperti altruisme dan kehendak bebas. Manusia memiliki potensi yang luar biasa akan pemahaman diri sendiri, dan cara untuk 
membantu orang lain mencapai pemahaman diri sendiri adalah dengan menjadi hangat dan mendukung. Pendekatan humanistik ini disebut juga dengan pendekatan optimis, dan memberikan dasar bagi psikologi positif.

\section{B. Faktor-faktor yang Mempengaruhi Perilaku Manusia}

Menurut Baron dan Byrne, terdapat beberapa faktor yang mendorong munculnya pemikiran dan perilaku sosial pada individu (Maryam, 2018), termasuk di dalamnya perilaku komunikasi, sebagai berikut :

\section{Perilaku dan karakter orang lain.}

Perilaku orang lain sering mempengaruhi pemikiran dan perilaku individu terhadap orang orang lain. Demikian juga halnya dengan karakter orang lain. Individu sering bereaksi terhadap karakteristik orang lain yang kasat mata, seperti penampilannya. Hasil penelitian Hassin dan Trope (2000) menujukkan bahwa individu tidak bisa mengabaikan penampilan orang lain, bahkan ketika secara sadar mencoba untuk mengabaikannya. Berikut eksperimen yang dilakukan oleh Hassin dan Trope. Peneliti memperlihatkan foto orang-orang yang dijadikan calon karyawan untuk bagian pekerjaan tertentu (seperti administrasi, pemeriksa mata, tukang listrik) kepada partisipan penelitian. Informasi tentang latar belakang para calon karyawan tersebut juga diberikan. Tugas para partisipan adalah menilai kecocokan orang-orang yang ada di foto tersebut dengan pada pekerjaan tertentu. 
Sebagian partisipan diminta untuk mengabaikan foto ketika membuat keputusan, sedangkan sebagian lainnya tidak diminta untuk mengabaikan. Hasilnya menunjukkan bahwa orang-orang dalam foto yang terlihat sebagai pekerja pada pekerjaan tertentu menerima penilaian yang lebih tinggi dibandingkan yang tidak. Bahkan hal ini juga berlaku pada partisipan yang diminta untuk mengabaikan foto dalam memberikan penilaian. Temuan ini menunjukkan bahwa reaksi individu terhadap orang lain dipengaruhi oleh penampilan luarnya.

\section{Proses kognitif.}

Cara berpikir dan perilaku individu terhadap orang lain dipengaruhi oleh ingatan individu tentang perilaku orang tersebut di masa lalu dan penyimpulan tentang kebenaran alasannya. Proses kognitif seperti ingatan dan penalaran (proses yang mendasari pikiran, keyakinan, ide, dan penilaian tentang orang lain yang dimiliki individu) memainkan peran penting dalam pemikiran dan perilaku sosial (Dayakisni \& Hudaniah, 2003).

\section{Variabel lingkungan (ekologi)}

Merupakan pengaruh lingkungan fisik. Hasil penelitian menunjukkan bahwa lingkungan fisik seperti cuaca, bau, dan kepadatan, mempengaruhi perasaan, pikiran, dan perilaku individu terhadap orang lain. Menurut Anderson, Bushman, \& Groom (1997) apakah individu mudah marah dan agresif ketika cuaca sedang panas dibandingkan ketika cuacanya sejuk dan nyaman ? Apakah bau yang 
harum mendorong individu lebih tertarik atau suka menolong orang lain?

\section{Konteks budaya}

Perilaku sosial sangat dipengaruhi oleh norma-norma sosial (aturan sosial tentang bagaimana seharusnya individu berperilaku dalam situasi tertentu), keanggotaan individu dalam kelompok, dan perubahan nilai-nilai sosial. Perilaku sosial dipengaruhi oleh konteks kebudayaan dimana perilaku sosial terjadi.

\section{Faktor biologis}

Merupakan warisan sifat-sifat dan genetik yang relevan dengan perilaku sosial. Bidang psikologi evolusioner memandang bahwa faktor biologis memainkan peran penting dalam perilaku sosial (Buss, 1995; Buss \& Shackelford, 1997). Misalnya dalam hal memilih pasangan. Mengapa individu memandang beberapa orang itu menarik yang kemudian dipilih menjadi pasangannya? Menurut perspektif evolusi, hal ini disebabkan karena karakteristik yang menarik (seperti bentuk wajah simetris, bentuk tubuh bagus, kulit bersih, rambut indah) dikaitkan dengan kapasitas reproduksi. Artinya bahwa karakteristik luar dari individu yang bisa dilihat tersebut dianggap mewakili kesehatan dan kekuatan dalam yang tidak bisa dilihat. Jadi, pemilihan pasangan yang memiliki karakteristik seperti ini, meningkatkan potensi bahwa individu tersebut akan berhasil dalam reproduksi. Hal inilah yang kemudian mempengaruhi pilihan individu 
dalam menentukan pasangan yang didasarkan pada aspek-aspek penampilan atau karakteristik luar yang dimiliki oleh seseorang. Para ahli psikologi sosial di bidang evolusi menekankan bahwa kecenderungan atau predisposisi perilaku sosial ini bisa terjadi atau mungkin juga tidak bisa terjadi dalam realitas, bergantung pada lingkungan dimana individu tinggal.

\section{RINGKASAN}

1. Pemeran utama dalam komunikasi menurut psikologi adalah manusia sebagai komunikan. Komunikasi ditentukan oleh perilaku manusia komunikan.

2. Psikologi berperan saat membicarakan tentang proses pemrosesan pesan yang diterima manusia.

3. Perilaku komunikasi manusia dijelaskan oleh empat pendekatan dalam psikologi, yaitu psikodinamika, behaviorisme, kognitif, dan humanistik.

4. Perilaku manusia dipengaruhi oleh faktor perilaku dan karakter orang lain, proses kognitif, lingkungan fisik, budaya, serta faktor biologis.

\section{LATIHAN}

1. Pendekatan psikodinamika, behaviorisme, kognitif, dan humanistik memiliki penekanan dalam menjelaskan perilaku manusia, termasuk perilaku komunikasi. Jelaskan secara singkat pandangan masing-masing pendekatan !

2. Berikan contoh kongkrit masing-masing pendekatan dalam kehidupan nyata ! 


\section{DAFTAR PUSTAKA}

Dayakisni, T., dan Hudaniah, 2003. Psikologi Sosial. Edisi Revisi. UMM Press, Malang.

King, Laura A. 2012. Psikologi Umum, Sebuah Pandangan Apresiasif, Buku 1. Terjemahan. Jakarta : Salemba Humanika.

King, Laura A. 2012. Psikologi Umum, Sebuah Pandangan Apresiasif, Buku 2. Terjemahan. Jakarta : Salemba Humanika.

Maryam, Effy W. 2018. Buku Ajar Psikologi Sosial. Sidoarjo : UMSIDA Press. 


\section{BAB 3}

\section{KOMUNIKASI INTRAPERSONAL}

Capaian Pembelajaran Mata Kuliah meliputi :

a. Aspek Sikap dan Tata Nilai :

(1) Bertakwa kepada Tuhan Yang Maha Esa dan mampu menunjukkan sikap religious

(2) Berkontribusi dalam peningkatan mutu kehidupan bermasyarakat, berbangsa, bernegara, dan kemajuan peradaban berdasarkan Pancasila

(3) Menghargai keanekaragaman budaya, pandangan, agama dan kepercayaan serta pendapat atau temuan orisinal orang lain

b. Aspek Ketrampilan Umum :

(1) Menguasai konsep teoritis hubungan manusia dengan lingkungan sosialnya

(2) Menguasai konsep teoritik komunikasi antar pribadi dan komunikasi massa

c. Aspek Ketrampilan Khusus :

Mampu menerapkan pemikiran logis, kritis, sistematis, dan inovatif dalam konteks pengembangan atau implementasi ilmu pengetahuan dan teknologi yang memperhatikan dan menerapkan nilai humaniora

d. Aspek Penguasaan Pengetahuan :

Mampu memahami dan menjelaskan peranan aspekaspek psikologi dalam proses komunikasi. 
Setiap individu yang terlibat dalam komunikasi akan mempersepsi stimuli sesuai karakteristik personal. Sebuah pesan yang sama bisa diberikan makna berlainan oleh individu yang berbeda. "Word's don't mean, people mean." Bab ini akan menguraikan proses penerimaan informasi, pengolahan, penyimpanan, dan pemanggilan atau penggunaan kembali. Proses pengolahan informasi ini dinamakan dengan komunikasi intrapersonal, meliputi sensasi, persepsi, memori, dan berpikir.

\section{A. Sensasi}

Sensasi merupakan tahap paling awal dalam penerimaan informasi. Menurut Benyamin B. Wolman, sensasi adalah pengalaman elementer yang segera, tidak memerlukan penguraian verbal, simbolis, atau konseptual, dan berhubungan dengan alat indera (Rakhmat, 2011). Sensasi akan mempengaruhi persepsi.

Sensasi dipengaruhi oleh faktor situasional dan personal. Faktor situasional mencakup ambang mutlak (abslolute threshold), yaitu batas minimal intensitas stimulus. Misalnya, mata hanya mampu menangkap stimulus yang memiliki panjang gelombang cahaya antara 380 sampai 780 nanometer. Manusia hanya sanggup menerima temperatur 10 derajat celcius sampai 45 derajat celcius. Di bawah 10 derajat celcius akan menggigil karena kedinginan, di atas 45 derajat celcius akan meringis kepanasan. Faktor personal yang mempengaruhi sensasi meliputi kapasitas alat indera, pengalaman, dan budaya. 


\section{Rangsangan / Stimulus $\rightarrow$ Panca Indera $\rightarrow$ Sensasi}

\section{Proses Penerimaan Rangsangan}

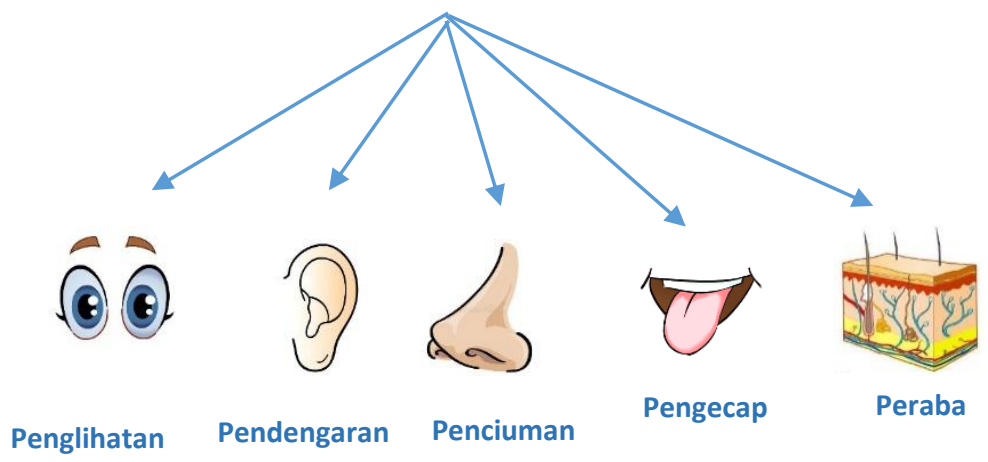

Rangsangan dari luar diterima oleh sel reseptor khusus pada masing-masing indera

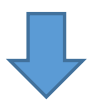

\section{Proses Tranduksi}

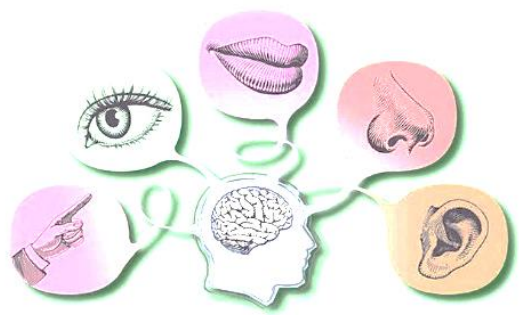

5 indera mengubah informasi menjadi implus-implus syaraf yang diteruskan ke otak untuk di proses 


\section{B. Persepsi}

Persepsi merupakan pengalaman tentang objek atau peristiwa dengan menyimpulkan atau memberikan makna atau menafsirkan stimulus inderawi (sensory stimuli). Persepsi juga diartikan sebagai pemberian makna terhadap sensasi. Sensasi merupakan bagian dari persepsi.
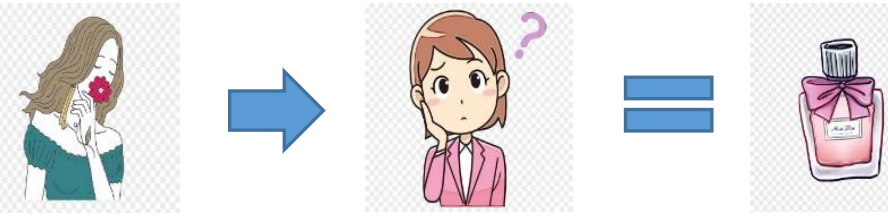

Ketika Riska mencium wangi bunga, Riska mengalami sensasi. la menyadari wewangian tersebut sama dengan parfum yang sering dikenakannya. Kesadaran atau interpretasi Riska terhadap wewangian bunga itulah yang disebut dengan persepsi.

Persepsi ditentukan oleh faktor perhatian (attention), faktor situasional, dan faktor personal.

\section{Perhatian}

Kenneth E. Andersen mengatakan bahwa perhatian merupakan proses mental ketika stimulus menonjol dalam kesadaran saat stimulus lainnya melemah (Rakhmat, 2011). Perhatian ditentukan oleh faktor eksternal dan internal. Faktor eksternal meliputi :

a. Gerakan.

Secara visual individu tertarik pada objek-objek yang bergerak. 
b. Intensitas stimuli

Individu cendrung memperhatikan stimulus yang lebih menonjol dari stimulus yang lain.

c. Kebaruan

Hal-hal yang baru, yang berbeda, akan menarik perhatian individu.

d. Perulangan

Hal-hal yang disajikan berkali-kali apalagi disertai dengan penambahan variasi, akan mampu menarik perhatian.

Faktor internal yang mempengaruhi perhatian meliputi :

a. Biologis

Kondisi biologis individu mempengaruhi perhatian terhadap stimuli. Misalnya, saat seseorang lapar, perhatiannya lebih banyak tertuju pada makanan.

b. Sosiopsikologi

Sikap individu, kebiasaan, dan motivasi akan mempengaruhi terhadap apa yang diperhatikan.

\section{Faktor Personal atau Faktor Fungsional yang Menentukan Persepsi}

Penentu persepsi bukanlah jenis atau bentuk stimulus, namun karakteristik individu yang memberikan respon atau yang melakukan persepsi. Faktor personal meliputi kebutuhan, pengalaman masa lalu, suasana emosional, latar belakang budaya, kerangka rujukan (frame of reference), dan hal-hal lain yang termasuk faktor personal. Dari sinilah Krech dan Crutchfield merumuskan dalil persepsi pertama, yaitu persepsi bersifat selektif secara fungsional, 
artinya bahwa objek-objek yang mendapat tekanan dalam persepsi individu biasanya objek-objek yang memenuhi tujuan individu yang melakukan persepsi.

\section{Faktor Situasional atau Faktor Struktural yang Menentukan Persepsi}

Faktor struktural berasal dari sifat stimuli fisik dan efek syaraf yang ditimbulkannya pada sistem syaraf individu. Menurut Gestalt, jika individu mempersepsi sesuatu, maka ia tidak melihat bagian-bagiannya, melainkan akan mempersepsinya sebagai suatu keseluruhan. Kohler menambahkan bahwa jika individu ingin memahami suatu peristiwa, maka harus memandangnya dalam hubungan keseluruhan. Jelasnya, untuk memahami seseorang, individu harus melihatnya dalam konteksnya, dalam lingkungannya, atau dalam masalah yang dihadapinya.

Dari sinilah Krech dan Crutchfield merumuskan dalil persepsi kedua, yaitu medan perseptual dan kognitif selalu diorganisasikan dan diberi arti oleh individu. Meskipun stimulus yang diterima individu tidak lengkap, individu akan melengkapinya dengan interpretasi yang konsisten dengan rangkaian stimulus yang dipersepsi.

Berkaitan dengan konteks, Krech dan Crutchfield merumuskan dalil persepsi ketiga, bahwa sifat-sifat perseptual dan kognitif dari substruktur ditentukan oleh sifat-sifat struktur secara keseluruhan. Jika individu dianggap sebagai anggota sebuah kelompok, maka semua sifat individu yang berkaitan dengan sifat kelompok akan dipengaruhi oleh keanggotaan kelompoknya, dengan efek asimilasi atau 
kontras. Asimilasi adalah sifat kelompok yang menonjolkan atau melemahkan sifat individu, sedangkan kontras adalah kecenderungan individu memberikan penilaian berlebihan jika individu melihat sifat objek persepsi bertolak belakang dengan sifat kelompoknya. Contoh kontras seperti skandal seks yang dilakukan oleh tokoh agama dipersepsi lebih buruk daripada skandal seks yang dilakukan oleh seorang artis.

Krech dan Crutchfield juga merumuskan dalil persepsi keempat, yaitu objek atau peristiwa yang berdekatan dalam ruang dan waktu atau menyerupai satu sama lain, cenderung ditanggapi sebagai bagian dari struktur yang sama (prinsip kesamaan dan kedekatan). Seringkali terjadi hal-hal secara berdekatan yang dianggap berkaitan atau memiliki hubungan sebab akibat.

\section{Memori}

Memori berperan penting dalam proses persepsi dan berpikir. Schlessinger dan Groves mendefinisikan memori sebagai sistem yang sangat terstruktur, yang menyebabkan organisme mampu merekam fakta tentang dunia dan menggunakan pengetahuannyauntuk membimbing perilakunya (Rakhmat, 2011).

Memori melewati proses perekaman (encoding), penyimpanan (storage), dan pemanggilan (retrieval). Perekaman merupakan pencatatan informasi melalui reseptor indera dan sirkit syaraf internal. Penyimpanan adalah menentukan berapa lama informasi berada dalam diri manusia, dalam bentuk apa, dan di bagian mana. Pemanggilan merupakan penggunaan informasi yang disimpan. 
Pemanggilan ini bisa dilakukan melalui empat cara, yaitu pengingatan (recall), pengenalan (recognition), belajar lagi (relearning), dan redintegrasi (redintegration).

Recall (pengingatan) merupakan proses aktif untuk menghasilkan kembali fakta dan informasi secara verbatim (kata per kata) tanpa petunjuk yang jelas. Misalnya pertanyaan "Apa yang dimaksud dengan memori ?" Jawaban yang disampaikan mendorong individu mencoba mengingat kembali fakta yang tersimpan dalam memori. Recognition (pengenalan) merupakan proses mengingat dengan mengenal kembali. Misalnya pertanyaan "Siapa nama presiden Indonesia saat ini ? Joko Widodo atau Susilo Bambang Yudhoyono ?" Pertanyaan sejenis ini menuntut pengenalan. Relearning (belajar lagi) adalah menguasai kembali informasi yang pernah diperoleh individu, misalnya menghafal. Redintegrasi adalah merekonstruksi seluruh masa lalu melalui petunjuk memori (memory cues) kecil, misalnya bau tertentu, tempat, nama, dan sebagainya. Saat mencium bau parfum tertentu, seseorang bisa mengingat peristiwa beberapa tahun yang lalu bersama mantan kekasihnya.

Mengapa bisa terjadi lupa ? Hal ini berkaitan dengan proses kerja memori, yang dijelaskan melalui teori aus (disuse theory), teori interferensi (interference theory), dan teori pengolahan informasi. Teori aus menjelaskan bahwa memori memudar karena waktu.

Lupa bisa dijelaskan oleh teori interferensi, menyatakan bahwa memori seperti kanvas dan pengalaman merupakan lukisan pada kanvas itu. Informasi terakhir yang diterima seseorang menyebabkan terhapusnya informasi yang 
masuk sebelumnya. Ada istilah inhibisi retroaktif dan inhibisi proaktif. Saat kita membaca buku ini pada halaman 10, kita berhasil mengingat dengan baik. Saat diteruskan ke halaman 11, ingatan kita pada informasi yang ada di halaman 10 berkurang, ini yang disebut inhibisi retroaktif (hambatan ke belakang). Ketika kita menghafal kamus bahasa inggris pada halaman 12 kita berhasil mengingat hingga 80 persen. Saat dilanjutkan di halaman selanjutnya, kita hanya mampu mengingat 30 persen. Semakin sering mengingat, ternyata kemampuan daya ingat lebih menurun. Inilah yang dinamakan inhibisi proaktif (hambatan ke depan).

Seseorang bisa lupa karena sengaja melupakan. Hal ini disebut hambatan motivasional. Psikologi klinis menyatakan bahwa peristiwa traumatis cenderung dilupakan individu.

Lupa juga dijelaskan oleh teori pengolahan informasi, yang menjelaskan bahwa informasi awalnya disimpan di gudang inderawi (sensory storage), kemudian masuk ke memori jangka pendek (short therm memory), lalu dilupakan atau dikoding untuk dimasukkan ke memori jangka panjang (long therm memory).

\section{Berpikir}

Proses keempat dalam komunikasi intrapersonal, yang mempengaruhi penafsiran individu terhadap stimulus adalah berpikir. Berpikir melibatkan proses sensasi, persepsi, dan memori. Berpikir menggunakan lambang verbal (angka, kali, pembagian, penjumlahan, pengurangan) maupun lambang grafis (gambar) yang menggantikan (merepresentasikan) objek atau peristiwa dalam benak 
individu. Berpikir digunakan untuk menyelesaikan permasalahan, menetapkan keputusan, dan mengasilkan kreatifitas.

Bagaimana individu berpikir ? Ada dua jenis berpikir yang digunakan individu, yaitu berpikir autistik (seperti melamun, fantasi, mengkhayal) dan berpikir realistik atau nalar (reasoning), yaitu berpikir sesuai dengan realitas. Berpikir realistik meliputi berpikir deduktif, induktif, dan evaluatif. Berpikir deduktif merupakan pengambilan kesimpulan berdasarkan hal-hal umum. Misalnya, semua manusia akan mati. Budi manusia. Jadi Budi akan mati. Berpikir induktif kebalikan berpikir deduktif, yaitu penarikan kesimpulan dari hal-hal khusus kemudian menimpulkan secara umum. Misalnya, Rini mahasiswa psikologi dan tangguh. Budi mahasiswa psikologi dan tangguh. Ardi dan Rani juga mahasiswa psikologi yang tangguh. Kesimpulannya mahasiswa psikologi memiliki ketangguhan. Jenis berpikir realistik yang terakhir adalah berpikir evaluatif, yaitu berpikir secara kritis, menilai ide atau gagasan berdasarkan kriteria tertentu.

\section{RINGKASAN}

1. Komunikasi intrapersonal merupakan proses penerimaan informasi, pengolahan, penyimpanan, dan pemanggilan atau penggunaan kembali, meliputi sensasi, persepsi, memori, dan berpikir.

2. Sensasi merupakan tahap awal dalam proses pengolahan informasi, yaitu proses menangkap stimulus melalui alat indera (belum terjadi pemaknaan). Persepsi merupakan 
proses selanjutnya setelah sensasi, yaitu proses penyimpulan atau pemberian makna atau menafsirkan stimulus inderawi (sensory stimuli). Memori merupakan proses penyimpanan informasi. Berpikir merupakan proses pengolahan informasi yang melibatkan proses sensasi, persepsi, dan memori.

3. Komunikasi intrapersonal sering dilakukan individu saat melakukan refleksi diri, juga saat mengambil keputusan.

\section{LATIHAN}

1. Komunikasi intrapersonal merupakan komunikasi yang dilakukan dalam diri seseorang. Jelaskan proses komunikasi intrapersonal tersebut !

2. Bagaimana pentingnya komunikasi intrapersonal bagi individu ? Jelaskan menurut perspektif psikologi !

\section{DAFTAR PUSTAKA}

Rakhmat, Jalaluddin. 2011. Psikologi Komunikasi, Cetakan Ke27. Bandung : Remaja Rosdakarya.

Maulana, Herdiyan dan Gumelar, Gumgum. 2013. Psikologi Komunikasi dan Persuasi. Jakarta : Akademia Permata. 


\section{BAB 4 \\ KOMUNIKASI INTERPERSONAL}

Capaian Pembelajaran Mata Kuliah meliputi :

a. Aspek Sikap dan Tata Nilai :

(1) Bertakwa kepada Tuhan Yang Maha Esa dan mampu menunjukkan sikap religious

(2) Berkontribusi dalam peningkatan mutu kehidupan bermasyarakat, berbangsa, bernegara, dan kemajuan peradaban berdasarkan Pancasila

(3) Menghargai keanekaragaman budaya, pandangan, agama dan kepercayaan serta pendapat atau temuan orisinal orang lain

b. Aspek Ketrampilan Umum :

(1) Menguasai konsep teoritis hubungan manusia dengan lingkungan sosialnya

(2) Menguasai konsep teoritik komunikasi antar pribadi dan komunikasi massa

c. Aspek Ketrampilan Khusus :

Mampu menerapkan pemikiran logis, kritis, sistematis, dan inovatif dalam konteks pengembangan atau implementasi ilmu pengetahuan dan teknologi yang memperhatikan dan menerapkan nilai humaniora

d. Aspek Penguasaan Pengetahuan :

Mampu memahami dan menjelaskan peranan aspekaspek psikologi dalam komunikasi. 
Komunikasi interpersonal menurut DeVito merupakan penyampaian pesan oleh satu orang dan penerimaan pesan oleh orang lain atau sekelompok kecil orang, yang berpeluang untuk memberikan umpan balik segera (Maulana \& Gumelar, 2013). Pada hakekatnya, komunikasi interpersonal adalah komunikasi antara komunikator dengan komunikan secara tatap muka, yang memungkinkan peserta komunikasi menangkap reaksi secara langsung, baik secara verbal maupun non verbal. Bab ini membahas tentang tujuan komunikasi interpersonal, elemen-elemen komunikasi interpersonal, dan faktor-faktor yang berperan dalam komunikasi interpersonal.

\section{A. Tujuan Komunikasi Interpersonal}

DeVito menyatakan bahwa komunikasi interpersonal memiliki tujuan sebagai berikut :

1. Proses belajar

Melalui komunikasi interpersonal, masing-masing pihak belajar mengenal sesuatu yang terjadi di sekitar lingkungannya, belajar tentang orang lain dan diri sendiri, dan mengetahui bagaimana penilaian atau respon orang lain tentang diri sendiri.

2. Membangun dan mempertahankan hubungan sosial Komunikasi interpersonal menghindarkan diri dari kesepian dan depresi.

3. Mempengaruhi

Upaya mempengaruhi sikap dan perilaku orang lain bisa dilakukan melalui komunikasi interpersonal. 
4. Bermain

Komunikasi interpersonal memberikan peluang untuk berdiskusi tentang hal-hal yang menyenangkan seperti hobi atau memberikan lelucon yang dapat menyeimbangkan hidup dan membuat pikiran istirahat sejenak dari hal-hal yang serius.

5. Menolong

Melalui komunikasi interpersonal, masing-masing pihak dapat menenangkan, menghibur, maupun memberi saran.

\section{B. Elemen-elemen Komunikasi Interpersonal}

DeVito mengemukakan bahwa komunikasi interpersonal dibangun dari tujuh unsur atau elemen (Maulana \& Gumelar, 2013. Elemen-elemen yang dimaksud sebagai berikut :

1. Pengirim dan penerima pesan

Komunikasi interpersonal sedikitnya melibatkan dua orang yang terdiri dari komunikator dan komunikan.

2. Pengkodean (coding) dan pemecahan kode

Dalam komunikasi interpersonal terjadi proses coding, yaitu proses pengalihan pikiran ke dalam bentuk lambang maupun kata-kata. Pemecahan kode adalah proses dimana komunikan melakukan interpretasi terhadap kode yang disampaikan komunikator.

3. Pesan (message)

Pesan yang disampaikan bisa berupa verbal maupun nonverbal.

4. Gangguan (noise) 
Gangguan adalah segala sesuatu yang mengganggu "kejernihan" pesan dalam proses komunikasi, sehingga bisa terjadi perbedaan pesan antara yang disampaikan komunikator dengan yang diterima komunikan.

5. Efek

Efek yang ditimbulkan dalam komunikasi interpersonal meliputi aspek kognitif (pengetahuan), aspek afektif (sikap, kepercayaan, emosi, perasaan), dan aspek konatif atau psikomotor (perilaku).

6. Saluran (channel)

Channel dalam komunikasi interpersonal merupakan media yang dilalui oleh pesan, seperti tatap muka, telepon, surat, televisi, media sosial, dan sebagainya.

7. Konteks

Konteks adalah situasi yang ada kaitannya dengan kejadian, meliputi fisik, sosial, psikologis, dan temporal.

\section{Faktor-faktor yang Berperan Dalam Komunikasi Interpersonal}

Komunikasi interpersonal ditentukan oleh faktorfaktor yang meliputi persepsi interpersonal, konsep diri, atraksi interpersonal, dan hubungan interpersonal.

\section{Persepsi Interpersonal}

Persepsi terhadap manusia disebut dengan persepsi interpersonal. Karakteristik persepsi interpersonal meliputi hal-hal sebagai berikut : 
a. Stimulus disampaikan melalui lambing-lambang verbal maupun grafis oleh pihak ketiga.

b. Memahami perilaku individu lain, termasuk motif perilakunya.

c. Dipengaruhi oleh faktor-faktor personal dan situasional perseptor dan individu yang dipersepsi.

d. Objek persepsi yaitu manusia selalu berubah-ubah atau dinamis.

Faktor-faktor yang mempengaruhi persepsi interpersonal, meliputi :

a. Faktor Situasional, mencakup :

1. Deskripsi verbal, yaitu apa yang diucapkan dalam proses komunikasi.

2. Petunjuk proksemik, yaitu penggunaan jarak dalam berkomunikasi.

3. Petunjuk kinesik, yaitu gerakan yang ditimbulkan orang dalam berkomunikasi, baik gerakan sebagian anggota badan (gesture) maupun kesleuruhan anggota badan (postur).

4. Petunjuk wajah (facial).

5. Petunjuk paralinguistik, berkaitan dengan bagaimana pengucapan pesan atau komunikasi, meliputi tinggi rendah suara, dialek, tempo bicara, kecepatan.

6. Petunjuk artifaktual, berkaitan dengan penampilan (appearance), meliputi bentuk tubuh, kosmetik, pakaian, tas, atribut pangkat, dan sebagainya. 
b. Faktor Personal, mencakup :

1. Pengalaman. Pengalaman individu mempengaruhi kecermatan persepsi.

2. Motivasi

3. Kepribadian

\section{Konsep Diri (Self-Concept)}

Konsep diri (self-concept) merupakan komponen kognitif mengenai diri (self) seseorang, yaitu merujuk pada keseluruhan keyakinan individu tentang dirinya (Kassin, et. al., 2008). Menurut Hazel Markus (1977), konsep diri terdiri dari komponen kognitif (self-schemas), yaitu keyakinan individu tentang dirinya sendiri yang memandu pemrosesan informasi yang relevan dengan dirinya (Kassin, et. al., 2008). Konsep diri merupakan keyakinan yang dimiliki individu tentang atribut yang dimilikinya (Brehm \& Kassin, 1996).

Kenrick et al. (2002) menyatakan bahwa konsep diri merupakan sebuah representasi mental yang menggambarkan pandangan dan keyakinan individu tentang dirinya sendiri. Konsep diri merupakan keyakinan (belief) individu tentang atribut yang melekat dalam diri sendiri, dimana keyakinan tersebut muncul setelah individu menyadari tentang dirinya dengan sifat-sifat yang melekat, baik melalui pengalaman pribadi, interaksi sosial, maupun dari proses perenungan (Suryanto, et. al., 2012).

Sumber-sumber yang membentuk konsep diri atau pengetahuan tentang diri (self) menurut Kenrick, et. al. (2002) sebagai berikut : 


\section{a. Proses persepsi diri (self perception process)}

Individu mempersepsi dirinya dengan mengamati perilakunya sendiri dalam keseharian.

b. Penaksiran yang direfleksikan (reflected appraisals process)

Individu melakukan penaksiran tentang dirinya sendiri dengan merefleksikan atau bercermin dari apa yang dikatakan orang lain tentang tentang dirinya. Evaluasi tentang diri individu dipengaruhi oleh apa yang diucapkan orang lain tentang individu. Misalnya, ketika orang tua mengatakan kepada anaknya bahwa dia pandai, anak akan berpikir seperti apa yang dikatakan orang tua tersebut.

c. Perbandingan sosial (social comparison)

Menurut Festinger (1954), individu memperoleh pengetahuan tentang dirinya dengan cara membandingkan dirinya (kemampuan, sikap, keyakinan, tingkah laku) dengan orang lain. Misalnya, ketika seseorang membandingkan bahwa nilainya lebih baik dari teman-teman lainnya, individu akan mengetahui tentang kemampuannya.

\section{d. Memori autobiografi (autobiographical memories)}

Filosof James Mill berpendapat bahwa fenomena self dan memori bagaikan dua sisi mata uang. Tanpa memori autobiografi (ingatan tentang urutan kejadian yang telah kita alami), kita tidak akan memiliki konsep diri yang koheren (Kassin, Fein, \& Markus, 2008). Seseorang bisa mengenali dirinya dari ingatan tentang pengalaman penting selama hidupnya. Ketika orang-orang diminta 
untuk mengingat kembali pengalamannya, mereka biasanya melaporkan lebih banyak peristiwa yang baru saja terjadi daripada masa lalu yang jauh ke belakang.

\section{e. Pengaruh budaya}

Konsep diri juga dipengaruhi oleh faktor budaya. Budaya individualisme dan kolektivisme mempengaruhi cara pandang seseorang terhadap konsep diri dan identitas diri. Menurut Hazel Markus dan Shinobu Kitayama (1991), sebagian besar bangsa Amerika Utara dan Eropa memiliki independent view tentang self, yang beranggapan bahwa self merupakan sebuah entitas yang berbeda, otonom (mandiri), dan unik. Keberhasilan seseorang dipandang karena usaha sendiri. Namun pada banyak negara di Asia, Afrika, dan Amerika Latin, orang-orang memegang interdependent view tentang diri (self), yang beranggapan bahwa self merupakan bagian dari sebuah jaringan sosial yang lebih besar yang mencakup keluarga, rekan kerja, dan orang-orang lain yang terhubung secara sosial. Pada pandangan ini, orang-orang tidak menganggap keberhasilannya karena usaha sendiri, melainkan karena kerja sama dalam kelompok. Jadi, orientasi budaya seseorang mempengaruhi caranya mempersepsi, mengevaluasi, dan mempresentasikan dirinya dalam relasi dengan orang lain (Maryam, 2018).

\section{Atraksi Interpersonal (Interpersonal Attraction)}

Daya tarik interpersonal (interpersonal attraction) menurut Baron dan Byrne (2003) merujuk pada penilaian atau 
sikap seseorang terhadap orang lain, yang diekspresikan melalui dimensi dari sangat suka (strong liking) hingga sangat tidak suka (strong dislike). Atraksi interpersonal juga bisa diartikan kesukaan kepada orang lain, sikap positif dan daya Tarik seseorang. Saat mengetahui siapa tertarik kepada siapa atau siapa menghindari siapa, dapat diramalkan arus komunikasi interpersonal yang akan terjadi (Rakhmat, 2011).

Faktor-faktor yang mendorong terjadinya atraksi interpersonal, sebagai berikut :

\section{a. Faktor personal (faktor dari dalam diri perseptor)}

\section{Harga diri}

Seseorang dengan harga diri yang tinggi cenderung memiliki keinginan untuk memberikan penghargaan sosial yang rendah, namun merasa percaya diri untuk mencarinya. Sedangkan seseorang dengan harga diri rendah, cenderung berkeinginan untuk memberikan penghargaan sosial yang tinggi, namun kurang percaya diri untuk memperoleh penghargaan tersebut (Brehm \& Kassin, 1996).

\section{Motivasi sosial}

Adanya motivasi sosial dalam diri individu yang berupa kebutuhan untuk berafiliasi (need for affiliation) dan kebutuhan untuk berhubungan intim (need for intimacy) mendorong individu untuk memuncukan ketertarikan dalam hubungan sosial.

\section{Tekanan emosional (stress)}

Jika seseorang berada dalam situasi yang mencemaskan atau menakutkan, cenderung 
menginginkan kehadiran orang lain. Kehadiran orang lain tersebut mendorong rasa suka pada individu tersebut (Dayakisni \& Hudaniah, 2003).

4. Perasaan atau mood positif (positive emotional arousal)

Kecenderungan tertarik atau menyukai orang lain yang kehadirannya bersamaan dengan munculnya perasaan positif, sekalipun perasaan positif ini tidak ada kaitannya dengan perilaku orang tersebut. Beberapa studi menunjukkan bahwa individu cenderung tertarik pada orang-orang yang ditemui saat sekelilingnya menyenangkan, sebaliknya ketertarikan terhadap orang lain berkurang saat sekelilingnya tidak menyenangkan seperti padat, bising, atau tercemar (Rotton, et. al., 1978; Glass \& Singer, 1972, dalam Dayakisni \& Hudaniah, 2003).

\section{b. Faktor situasional (faktor eksternal)}

\section{Ketertarikan fisik}

Penampilan fisik yang menarik memiliki keuntungan sosial, yaitu memunculkan ketertarikan pada orang lain dan lebih mudah mendapatkan bantuan (Hatfield \& Sprecher, 1986, dalam Suryanto et. al., 2012). Sebuah penelitian menunjukkan hasil bahwa sebagian besar orang percaya jika laki-laki dan perempuan yang menarik memiliki krakteristik positif, seperti menampilkan ketenangan, mudah bergaul, mandiri, dominan, gembira, seksi, mudah beradaptasi, sukses, lebih maskulin (untuk laki-laki) dan lebih feminin 
(untuk wanita) dibandingkan orang yang tidak menarik Baron \& Byrne, 2008).

\section{Kesamaan (similarity)}

Individu cenderung menyukai orang-orang yang memiliki kesamaan dengan dirinya, dalam hal sikap, nilai, minat, latar belakang, atribut fisik, dan kepribadian. Mengapa demikian ? Pertama, saat memiliki kesamaan sikap, maka seluruh unsur kognitif bisa konsisten. Kedua, adanya kesamaan cenderung lebih mudah menyetujui pandangan dan mendukung keyakinan tentang kebenaran pandangan tersebut. Ketiga, kesamaan mendorong terjadinya interaksi yang terjalin di masa yang akan datang akan positif dan memberikan keuntungan (Dayakisni \& Hudaniah, 2003).

\section{Kemampuan (ability)}

Individu cenderung menyukai orang lain yang secara sosial memiliki kemampuan, kompeten, dan cerdas karena bisa memberikan keuntungan (reward). Keuntungan tersebut di antaranya mampu membantu individu menyelesaikan masalah, mampu memberikan nasehat, dan sebagainya.

\section{Kedekatan (proximity)}

Orang cenderung menyukai orang lain yang tempat tinggalnya berdekatan. Hasil penelitian Festinger tentang pola pertemanan di perumahan mahasiswa yang sudah menikah menunjukkan bahwa mahasiswa akan berteman dengan orang yang dekat dengan tempat tinggalnya dibandingkan dengan yang jauh 
(Suryanto et. al., 2012). Terdapat beberapa alasan mengapa kedekatan menjadi faktor penentu ketertarikan interpersonal. Pertama, orang yang secara fisik dekat akan lebih mudah ditemui daripada orang yang jauh. Kedua, kedekatan seringkali berkaitan dengan kesamaan. Ketiga, kedekatan biasanya akan meningkatkan keakraban.

\section{Keakraban (familiarity)}

Orang yang tinggal berdekatan akan menjadi akrab, sehingga bisa memperkuat atraksi interpersonal. Semakin sering bertemu dengan seseorang, akan meningkatkan rasa suka terhadap orang tersebut (Taylor et. al., 2009).

\section{Kesukaan timbal balik (reciprocal liking)}

Saat seseorang mengetahui bahwa orang lain menyukai dirinya, bisa mempengaruhi ketertarikan kepada orang tersebut. Secara umum individu menyukai orang yang juga menyukai dirinya, sebaliknya cenderung tidak menyukai orang lain yang tidak menyukai dirinya.

7. Saling melengkapi atau komplementer (complementary)

Tidak selamanya orang menyukai orang lain karena adanya kesamaan-kesamaan. Perbedaan di antara individu juga bisa memunculkan ketertarikan satu sama lain. Misalnya, individu yang memiliki kepribadian dominan, biasanya hubungan interpersonal yang terjalin dengan orang yang samasama dominan tidak lama. Individu yang dominan 
membutuhkan partner yang submisif yang akan saling membantu memenuhi kebutuhan-kebutuhan mereka. Perilaku yang saling melengkapi memungkinkan untuk kepribadian dominan-submisif (Dayakisni \& Hudaniah, 2003).

Komunikasi interpersonal bisa efektif apabila proses komunikasi merupakan hal yang menyenangkan bagi komunikan (Rakhmat, 2011).

\section{Hubungan Interpersonal}

Komunikasi yang efektif juga ditandai dengan hubungan interpersonal yang baik. Kegagalan komunikasi sekunder terjadi jika isi pesan komunikator dipahami namun hubungan di antara komunikan menjadi buruk (Rakhmat, 2011). Komunikasi tidak hanya menyampaikan isi pesan, namun juga menentukan kualitas hubungan interpersonal. Komunikasi bukan hanya menentukan content melainkan juga relationship.

Sejumlah model atau teori mencoba menganalisis tentang hubungan interpersonal. Model pertama yaitu pertukaran sosial, bahwa hubungan interpersonal sebagai suatu transaksi dagang. Individu berhubungan dengan individu lain mengharapkan hal-hal yang mampu memenuhi kebutuhannya. Thibault dan Kelley menyampaikan bahwa setiap individu melakukan hubungan social berdasarkan pertimbangan ganjaran (reward) dan biaya (punishment). 
Model kedua adalah model peranan, menjelaskan bahwa hubungan interpersonal sebagai panggung sandiwara, setiap individu harus memainkan peranannya sesuai "naskah" yang telah dibuat masyarakat. Hubungan interpersonal berkembang baik jika setiap individu bertindak sesuai ekspektasi peranan (role expectation) dan tuntutan peranan (role demands), mmeiliki ketrampilan peranan (role skills), dan terhindar dari konflik peranan (Rakhmat, 2011).

Model ketiga yaitu model permainan, bahwa individu saling berhubungan dalam berbagai permainan, yang didasari oleh tiga bagian kepribadian manusia, meliputi orang tua, orang dewasa, dan anak. Orang tua merupakan asumsi dan perilaku yang diterima individu dari orang tua atau orang yang dianggap sebagai orang tua. Orang dewasa merupakan bagian yang mengolah informasi secara rasionalsesuai situasi, berkaitan dengan pengambilan keputusan secara sadar. Anak merupakan unsur kepribadian yang mengandung potensi intuisi, spontanitas, kreativitas, dan kesenangan. Dalam hubungan interpersonal individu menampilkan salah satu aspek kepribadian tersebut dan individu lain membalasnya dengan salah satu aspek kepribadian tersebut juga.

Model keempat adalah model interaksional, memandang bahwa hubungan interpersonal sebagai suatu sistem. Untuk menganalisanya, harus melihat karakteristik individu yang terlibat, sifat kelompok, dan sifat lingkungan.

Hubungan interpersonal berlangsung melewati tiga tahapan, yaitu tahap pembentukan hubungan interpersonal, 
peneguhan hubungan, dan pemutusan hubungan. Tahap pertama yaitu tahap pembentukan hubungan interpersonal atau disebut tahap perkenalan, meliputi fase kontak permulaan, ditandai usaha kedua belah pihak untuk "menangkap" informasi dari reaksi partner. Masing-masing pihak berusaha menggali secara cepat identitas, sikap, dan nilai partner. Jika ada kesamaan, mulai dilakukan proses pengungkapan diri, namun jika merasa berbeda akan berusaha menyembunyikan dirinya dan mungkin diakhiri. Pada tahap ini informasi berupa data demografis, usia, pekerjaan, tempat tinggal, keadaan keluarga, sikap atau pendapat tentang orang atau objek, dan sebagainya. Informasi tidak hanya diperoleh melalui komunikasi verbal, namun juga komunikasi nonverbal.

Tahap selanjutnya yaitu peneguhan hubungan interpersonal, dipengaruhi oleh empat faktor meliputi keakraban, kontrol (kesepakatan tentang siapa mengontrol siapa dan kapan), ketepatan respon, dan ketepatan nada emosional yang tepat.

Tahapan berikutnya adalah pemutusan hubungan interpersonal. Nye menyebutkan lima sumber konflik yang memicu pemutusan hubungan interpersonal meliputi kompetisi, dominasi, kegagalan, provokasi, dan perbedaan nilai (Rakhmat, 2011).

Beberapa faktor mampu menumbuhkan atau mengembangkan hubungan interpersonal dalam komunikasi 
interpersonal, antara lain percaya (trust), sikap suportif, dan sikap terbuka (open-mindedness).

\section{RINGKASAN}

1. Komunikasi interpersonal merupakan komunikasi yang dilakukan antar individu.

2. Komunikasi interpersonal dipengaruhi faktor persepsi interpersonal, konsep diri, atraksi interpersonal, dan hubungan interpersonal. Masing-masing faktor berpengaruh terhadap efektivitas komunikasi interpersonal.

\section{LATIHAN}

1. Komunikasi interpersonal sangat diperlukan dalam kehidupan sosial individu. Bagaimana pentingnya komunikasi interpersonal untuk memenuhi kebutuhan psikologis individu dalam kehidupan sosial ?

2. Komunikasi interpersonal dipengaruhi faktor persepsi interpersonal, konsep diri, atraksi interpersonal, dan hubungan interpersonal. Bagaimanakah pengaruh keempat faktor tersebut terhadap efektivitas komunikasi interpersonal ?

\section{DAFTAR PUSTAKA}

Baron, R.A., dan Byrne, D., 2003. Psikologi Sosial Jilid 1. Edisi Kesepuluh. Erlangga, Jakarta.

Brehm, S.S., dan Kassin, S.M., 1996. Social Psychology. Third Edition. Prentice-Hall, London. 
Dayakisni, T., dan Hudaniah, 2003. Psikologi Sosial. Edisi Revisi. UMM Press, Malang.

Maulana, Herdiyan dan Gumelar, Gumgum. 2013. Psikologi Komunikasi dan Persuasi. Jakarta : Akademia Permata. Rakhmat, Jalaluddin. 2011. Psikologi Komunikasi, Cetakan Ke27. Bandung : Remaja Rosdakarya.

Suryanto, Putra, M.G.B.A., Herdiana, I., dan Alfian, I.N., 2012. Pengantar Psikologi Sosial. Airlangga University Press, Surabaya. 


\section{BAB 5 \\ KOMUNIKASI KELOMPOK}

Capaian Pembelajaran Mata Kuliah meliputi :

a. Aspek Sikap dan Tata Nilai :

(1) Bertakwa kepada Tuhan Yang Maha Esa dan mampu menunjukkan sikap religious

(2) Berkontribusi dalam peningkatan mutu kehidupan bermasyarakat, berbangsa, bernegara, dan kemajuan peradaban berdasarkan Pancasila

(3) Menghargai keanekaragaman budaya, pandangan, agama dan kepercayaan serta pendapat atau temuan orisinal orang lain

b. Aspek Ketrampilan Umum :

(1) Menguasai konsep teoritis hubungan manusia dengan lingkungan sosialnya

(2) Menguasai konsep teoritik komunikasi antar pribadi dan komunikasi massa

c. Aspek Ketrampilan Khusus :

Mampu menerapkan pemikiran logis, kritis, sistematis, dan inovatif dalam konteks pengembangan atau implementasi ilmu pengetahuan dan teknologi yang memperhatikan dan menerapkan nilai humaniora

d. Aspek Penguasaan Pengetahuan :

Mampu memahami dan menjelaskan peranan aspekaspek psikologi dalam komunikasi. 
Manusia selalu diciptakan untuk dapat saling bersosialisasi terhadap manusia yang lainnya. Kodrat sebagai manusia adalah berhubungan dan menjalin hubungan yang positif terhadap pihak lainnya. Pada saat manusia menjalin hubungan dengan pihak lain inilah, komunikasi menjadi media yang paling efektif sekaligus menjadi media paling utama dalam proses berkelompok. Kelompok adalah sekumpulan manusia yang berada dalam satu ikatan, yang dapat mempersatukan mereka dengan tujuan dan visi yang sama dalam sebuah organisasi. Kelompok pasti melibatkan interaksi antar anggota-anggotanya dan itu yang membuat sebuah kelompok menjadi dinamis. Menurut Baron \& Byrne (1979) bahwa kelompok memiliki dua tanda psikologis, Pertama, anggota-anggota kelompok merasa terikat dengan kelompok (sense of belonging), kedua, nasib anggota-anggota kelompok saling bergantung sehingga hasil setiap orang terkait dalam cara tertentu dengan hasil yang lain.

Pada bagian ini, penulis akan membahas pembagian kelompok menjadi empat dikotomi yaitu primer-sekunder, ingroup-outgroup, rujukan-keangotaan, dan deskriptifpreskriptif. Pembahasan kali ini juga akan membahas tentang komunikasi kelompok kaitannya dengan aliran-aliran yang ada dalam psikologi. Komunikasi kelompok ini menjadi pembahasan yang menarik dalam psikologi karena sebagai ilmu yang mempelajari perilaku dan proses mental, komunikasi kelompok erta kaitannya dengan gaya dan cara manusia dalam berkomunikasi dengan anggota kelompoknya atau kelompok lain. Komunikasi kelompok mulai menjadi 
pembahasan yang luas di psikologi khususnya psikologi sosial sejak pertengahan tahun 1960 yang dimulai dengan adanya persepsi sosial. Pada tahun 1974 sampai 1980, studi tentang kelompok dominan dilakukan oleh ahli psikologi sosial. Pembahasan tentang komunikasi dalam kelompok dimulai dengan temuan para manajer tentang komunikasi kelompok menjadi wadah yang efektif untuk mengeluarkan gagasan dan ide-ide kreatif, para pendidik menemukan bahwa komunikasi kelompok sebagai metode pendidikan yang efektif, para psikolog dan psikiater menjadikan komunikasi kelompok sebagai wadah atau alat untuk menyembuhkan pasien dengan gangguan mental, yang terakhir ini yang akan sedikit disinggung mengenai komunikasi kelompok dalam metode treatmen atau penyembuhan trerhadap orang dengan gangguan mental oleh psikolog. Penyembuhan ini mulai dari metode, treatmen, dan evaluasi keefektifan komunikasi kelompok dalam menyembuhkan individu dengan gangguan mental.

Temuan-temuan ini tentu memperkaya pemahaman tentang efektivitas komunikasi kelompok dan dampak terhadap perilaku individu sehar-hari. Seberapa efektif komunikasi kelompok mampu merubah keadaan manusia menjadi lebih baik ? Pada saat kita membahas tentang komunikasi kelompok, hal yang harus kita ingat adalah bahwa kelompok bukanlah sekedar kumpulan manusia yang sedang antri di pasar, bukan sekumpulan orang yang berada di terminal bus atau stasiun kereta, dan bukan sekumpulan orang yang ada di gedung bioskop. Orang-orang yang 
berkumpul seperti itu dinamakan agregat. Hal yang perlu diperhatikan seperti yang sudah dibahas di atas adalah bahwa kelompok adalah sekumpulan manusia yang berkumpul dan memiliki ikatan batin, emosional, dan tujuan serta visi yang sama. Pada selanjutnya kita akan langsung membahas tentang klasifikasi dalam kelompok yang telah dibagi menjadi empat domain tadi.

\section{A. Klasifikasi Kelompok}

\section{Kelompok Primer-Kelompok Sekunder}

Kelompok primer merupakan kelompok yang terdiri dari beberapa anggota kelompok yang merasa terikat secara emosional, batin, dan memiliki kelekatan yang tinggi pada kelompok itu ( Cooley, 1909). Biasanya yang dinamakan dengan kelompok primer adalah rekan sejawat di kantor, teman dalam organisasi seperti di lingkungan kampus, serta lingkungan keluarga.

Kelompok sekunder merupakan kebalikan dari kelompok primer yaitu tidak adanya ikatan batin bagi dan emosional antar anggotanya. Contoh pada kelompok sekunder adalah organisasi massa, serikat buruh yang melakukan demonstrasi, da lain-lain. Mereka berkumpul dalam kelompok disebabkan satu tujuan yang sama saja tetapi belum menimbulkan variabel dari komunikasi dari kelompok tersebut. Kita dapat melihat perbedaan antara kelompok primer dan kelompok sekunder melalui perbedaan karakteristik komunikasinya. Pertama, komunikasi dalam kelompok primer mendalam dan meluas. Komunikasi seperti 
tidak ada batasnya dan hampir tidak ada hambatan dalam berkomunikasi ini. Komunikasi sekunder merupakan komunikasi yang ada batasannya dan sifatnya tersembunyi. Hal-hal yang diungkapkan tidak bersifat pribadi tetapi sangat umum. Kedua, komunikasi primer menekankan pada hal-hal yang bersifat personal. Kita dapat menyatakan segala informasi kita terhadap orang lain. Kita juga mampu lebih percaya dan mendalami orang lain lebih dekat. Kata-kata yang digunakan adalah siapa dia bukan apakah dia. Ketiga, komunikasi primer lebih menekankan hubungan daripada sekedar konten dari percakapannya. Hubungan yang hangat merupakan komunikasi dalam kelompok primer ini untuk membangun tujuan bersama yang lebih baik lagi. Suatu perusahaan yang anggotanya sudah mengikat secara personal lebih dapat membangun komunikasi yang kontennya lebih ke memperbaiki hubungan yang baik antar personal agar mereka dapat bekerjasama dengan baik memajukan perusahaan. Komunikasi seknder yang terpenting adalah konten dari apa yang dibicarakan daripada memperbaiki hubungan antar personal. Hal ini disebabkan komunikasi sekunder terbatas dan tidak luas, maka dalam dunia kerja misalkan, cara memajukan perusahaan dari para karyawan tidak dengan cara membangun hubungan personal dahulu tetapi dengan membicarakan langsung ke topik apa yang harus dikerjakan untuk bersama memajukan perusahaan ke depannya. 


\section{Kelompok ingroup dan outgroup}

Ingroup dan outgroup ini merupakan proses kelompok yang selalu dibahas dalam menjelaskan dinamika kelompok. Ingroup selau diidentikkan dengan "kita" dan outgroup diidentikkan dengan "mereka". Siapa saja yang masuk wilayah kita ? Ingroup tentu merupakan bagaimana anggota kelompok saling merasa terikat satu sama lain, merasa memiliki kelompok, dan banga akan identitas kelompoknya. Hal ini yang biasa disebut dengan kohesivitas. Pada ingroup, identitas adalah hal yang sangat mudah dimainkan untuk memperkuat posisi ingroup-nya dan membuang kelompok outgroup-nya. Eksperimen yang dilakukan oleh Sherif dkk (1961) menjelaskan bahwa ada anakanak yang ditempatkan dalam satu tempat dari latar belakang yang berbeda, mulai dari etnis, sosial, jenjang pendidikan, dan agama. Mereka yang awalnya bermain sendiri-sendiri lama kelamaan mulai membuat ingroup nya dengan cara membuat kelompok dengan latar belakang yang sama. Permainan dimulai dan mereka saling serang dan bermusuhan, kata-kata rasisnya keluar dari dua kelompok yang berbeda ini. Hal seperti ini meningkatkan kohesivitas grup dan menurunkan toleransi terhadap outgroup dalam arti lain muncul sterotipe terhadap lawan-lawan yang berbeda. Peneliti melakukan pendamaian terhadap dua kelompok ini dengan cara dua kelompok yang bertikai ini harus mencari cara untuk mengalahkan musuh bersama. Akhirnya dua kelompok yang berbeda ini akhirnya mampu bersatu dengan posisi berbeda latar belakang yang ada dan mengesampingkan atau 
menurunkan posisi ingroup-nya dan meningkatkan atau menyeimbangkan posisi outgroup dengan ingroup.

\section{Kelompok Keanggotaan dan Kelompok Rujukan}

Jenis kelompok ini dicetuskan oleh Newcomb yang menilai ada istilah kelompok keanggotaan dan kelompok rujukan. Hal ini berdasarkan studi yang dilakukan pada tahun 1930 terhadap seluruh mahasiswa Bennington College. Bennington College yang merupakan kampus liberal dan dihuni oleh civitas academia yang liberal merupakan masuk dalam kelompok keanggotaan (membership group) dan tidak semua mahaiswa yang sekolah disana mengikuti gaya pemikiran yang liberal tersebut justru tetap mempertahankan gaya konservatifnya, maka itu disebut dengan kelompok rujukan (reference group).

Kelompok rujukan ini bisa dijadikan standar ukuran dalam bersikap dan berperilaku. Jika kelompok itu pantas untuk diikuti, itu yang disebut dengan kelompok rujukan positif (positive reference group) dan jika kelompok itu tidak pantas untuk diikuti maka disebut dengan kelompok rujukan negatif ( negative reference group). Komunikasi kelompok menjadi cara paling efektif untuk mencegah terjadinya polarisasi antar kelompok dan menciptakan keseimbangan antara ingroup dan outgroup. Metode sharing kebudayaan dari kelompok yang memiliki latar belakang yang berbeda juga menjadi sarana yang tepat dalam menyatukan latar belakang yang berbeda. Keadaan ingroup dan outgroup yang tidak seimbang terjadi karena adanya prasangka, stereotipe, dan 
atribusi yang dilemparkan satu kelompok ke kelompok lain yang berbeda ( Baron \& Byrne, 2010).

\section{Kelompok Deskriptif dan Kelompok Preskriptif}

Kelompok deskriptif merupakan klasifikasi kelompok yang dapat terbentuk secara alamiah dan melalui beberapa tahapan secara alami. Barlund dan haimann (1960) mengklasifikasikan kelompok itu berkaitan tugas-tugas yang diemban. Kelompok ini diklasifikasikan sebagai berikut:

Tabel 5.1

\begin{tabular}{|l|l|}
\hline \multicolumn{1}{|c|}{ Nama Kelompok } & \multicolumn{1}{|c|}{ Tujuan } \\
\hline Kelompok sepintas & $\begin{array}{l}\text { Fokusnya untuk membina } \\
\text { hubungan antar manusia yang } \\
\text { hangat }\end{array}$ \\
\hline Kelompok pertemuan & $\begin{array}{l}\text { Fokusnya sebagai saran dalam } \\
\text { belajar untuk kelompoknya } \\
\text { sendiri. Misal, kelompok } \\
\text { diskusi, kelompok terapi di } \\
\text { rumah sakit jiwa atau klinik } \\
\text { kesehatan }\end{array}$ \\
\hline Kelompok Penyadar & $\begin{array}{l}\text { Fokusnya untuk menciptakan } \\
\text { identitas sosial politik yang } \\
\text { baru }\end{array}$ \\
\hline Kelompok Katarsis & $\begin{array}{l}\text { Fokusnya untuk saling berbagi, } \\
\text { melepaskan perasaan dan rasa } \\
\text { frustasi kelompoknya }\end{array}$ \\
\hline Kelompok Belajar & $\begin{array}{l}\text { Fokusnya menggali informasi } \\
\text { menyelesaikan } \\
\text { memecahkan masalah tugas, }\end{array}$ \\
\hline Kelompok Tugas &
\end{tabular}


Kelompok preskriptif merupakan langkah-langkah yang harus ditempuh untuk mencapai tujuan dari kelompok itu. Masing-masing kelompok yang telah diklasifikasikan harus memiliki langkah-langkah konkret untuk mendapatkan tujuannya itu. Hal itu tentu harus diperkuat dengan komunikasi ayng efektif antar anggota kelompok untuk mecapai tujuan yang diharapkan.

Pembahasan di atas memudahkan pembaca khususnya para mahasiswa untu menjadikan sebagai referensi dalam mengambil mata kuliah psikologi komunikasi yang ada kaitannya dengan komunikasi kelompok. Perilaku kelompok pada dasarnya merupakan perilaku yang sering muncul ketika mengamati interaksi antar anggota kelompok baik itu kelompok kerja, kelompok organisasi sekolah atau kampus dan kelompok lainnya. Kelompok yang memiliki ikatan batin dan emosional tentu lebih mudah diamati dan dikaji secara komprehensif karena disitu memiliki dinamika yang kuat. Dinamika ini yang disebut sebagai dinamika kelompok bahwa kelompok itu selalu hidup dan bergerak secara dinamis dipenuhi dengan tantangan yang kuat, komunikasi yang efektif, dalam menuju visi dan tujuan dari kelompok itu. Tujuan dari kelompok itu selalu ada dan anggota kelompok terkadang memahami kelompoknya berbeda-beda, hal inilah diperlukan proses kohesivitas dan konformitas. Konformitas merupakan proses dimana anggota kelompok melakukan suatu hal dan diikuti oleh kelompok lain. Kiesler dan Kiesler (1969) menjelaskan bahwa konformitas terjadi karena adanya perubahan perilaku menuju standar norma kelompok sebagai 
akibat adanya tekanan dari kelompok. Perubahan perilaku dalam kelompok sering terjadi karena difasilitasi oleh komunikasi yang seimbang antara pemimpin kelompok dengan bawahannya. Pemimpin mengajak anggotanya untuk dapat mencapai norma yang telah ditetapkan sehingga semua anggota mampu mencapai norma itu dan pada akhirnya akan merasa menjadi anggota dari kelompk yang bersangkutan, ini yang dinamakan dengan kohesivitas.

Pembahasan mengenai komunikasi kelompok tidak hanya berhenti sampai pembagian klasifikasi kelompok saja. Aliran-aliran dalam psikologi menjelaskan komunikasi kelompok juga merupakan pembahasan yang tidak dapat dilewatkan. Hal ini dapat dipahami bahwa psikologi dapat menjelaskan tentang adanya proses komunikasi kelompok yang dilakukan oleh para anggota kelompok yang ada. Seperti sudah dibahas di atas, bahwa dalam komunikasi kelompok terdapat variabel-variabel psikologi yang muncul dengan pendekatan berbagai macam pendekatan yang ada. Ada tiga aliran dalam psikologi yaitu psikoanalisis, behaviorisme, humanistik, dan semuanya dapat menjelaskan tentang adanya komunikasi kelompok.

\section{B. Kelompok menurut Perspektif Psikologi}

\section{Psikoanalisis}

Aliran ini dicetuskan oleh Sigmund Freud sebagai bapak psikoanalisis. Pada teori ini Freud menjelaskan ada dua teori yang populer yaitu struktur kepribadian dan perkembangan psikoseksual. Struktur kepribadian pada 
manusia ini menurut Freud ada tiga yaitu Id, ego, dan superego. Id merupakan struktur bawah sadar pada manusia yang selalu ingin segera dipenuhi, ego merupakan struktur sadarnya manusia dan dapat berpikir realitas, sementara superego merupakan segi normatifnya manusia yang sesuai dengan aturan dan sebagainya ( Alwisol, 2007). Perkembangan psikoseksual pada manusia meliputi lima tahapan yang ada yaitu fase oral, fase anal, fase falik, fase laten, dan fase genital ( Latipun, 2005).

Pada proses komunikasi kelompok dapat diuraikan secara lebih mendalam, sebagai berikut :

a) Perkembangan psikosesual fase oral merupakan perkembangan kepribadian yang menitikberatkan pada kenikmatan di mulut. Manusia sejak bayi harus segera dipenuhi kebutuhan akan makan dan minumnya (jika bayi harus dipenuhi minum susu ibu). Jika tidak terpenuhi maka akan mengalami gangguan kepribadian. Komunikasi pada manusia dapat tercapai apabila fase oral pada manusia telah terpenuhi dan matang sehingga manusia itu mampu melakukan komunikasi yang baik. Hal ini sangat membantu pada perkembangan komunikasi saat manusia berada dalam kelompok. Manusia yang terpenuhi fase oralnya akan mudah dalam berkomunikasi dan tidak mudah terjebak dalam konflik antar budaya yang berbeda seperti kasusnya ingroup dan outgroup.

b) Pada struktur kepribadian, dapat dilihat komunikasi kelompok yang dipengaruhi oleh struktur id, yaitu komunikasi yang selalu membuat kelompok terpecah 
belah dan mengalami konflik kelompok. Hal ini karena struktur id lebih dominan pada diri manusia sehingga manusia mudah melakukan hal-hal yang negatif dalam kelompoknya (insting mati/thanatos).

\section{Behaviorisme}

Aliran ini menitiberatkan bahwa perilaku dipengaruhi oleh lingungan sekitar. Hal ini melihat manusia seperti robot yang hanya bersifat statis dan tidak dinamis. Aliran ini dipelopori oleh tokoh-tokoh seperti Ivan Pavlov, Edward Thorndike, dan Albert Bandura ( Santrock, 2007). Konsep stimulus respon serta sistem reward dan punishment merupakan konsep andalan dari aliran behaviorisme. Pada komunikasi kelompok, aliran dapat dijelaskan secara jelas dan lengkap, sebagai berikut :

a) Komunikasi dalam kelompok dapat tercapai apabila adanya stimulasi yang tepat dari pemimpin atau anggota lain yang memiliki pengaruh. Hal ini yang dinamakan dengan konformitas, yaitu perilaku akan ditiru dan diikuti oleh anggota kelompok yang lainnya karena telah mendapatkan figur yang tepat. Anggota lain akan merespon dengan cepat dan tanggap dengan apa yang dilakukan oleh orang yang memiliki pengaruh dalam kelompoknya.

b) Figur yang dapat dijadikan model untuk diimitasi oleh anggta lainnya. Ini sesuai dengan konsep dari Bandura, yang menjelaskan bahwa manusia mudah meniru apa yang dilihat terutama hal-hal yang dianggap menarik, baik, 
dan dilakukan oleh figur yang tepat. Proses modelling akan terjadi disana.

\section{Humanistik}

Aliran yang dipelopori oleh Abraham Maslow dan Carl Rogers ini menjelaskan bahwa manusia merupakan makhluk yang dapat mengaktualisasikan dirinya dan mampu memaknai dirinya sendiri. Maslow terkenal dengan teori piramida aktualisasi diri dan rogers terkenla dengan teori self. Terkait komunikasi kelompok, aliran ini menjelaskan sebagai berikut :

a) Proses aktualisasi diri yang terdiri dari beberapa tahapan sebelum tercapai aktualisasi diri, merupakan bagian dari puncak dari manusia dalam melakukan komunikasi kelompok. Manusia yang mampu berbicara di depan kelompoknya dengan baik bahkan dapat melakukan koordinasi dengan anggota kelompoknya dengan handal, dianggap sebagai puncak dari aktualisasi diri yang dijelaskan oleh Maslow ini.

b) Adanya penghargaan dari teman kerjanya akan meningkakan rasa percaya diri dari manusia dalam melakukan komunikasi kelompoknya.

c) Komunikasi merupakan sarana untuk melakukan pemaknaan terhadap dirinya sendiri sekaligus introspeksi untuk dapat menjadi pribadi yang lebih baik (teori self).

d) Komunikasi intrapersonal kaitannya dengan persepsi, memori, sensasi merupakan cara atau media manusia untuk melihat dirinya sendiri. Hal ini bisa dijadikan standar manusia dalam bersikap dan berperilaku. 


\section{Pengaruh Kelompok pada Perilaku Komunikasi}

Terdapat tiga macam pengaruh kelompok pada perilaku komunikasi individu, yaitu konformitas, fasilitasi social, dan polarisasi.

\section{Konformitas (conformity)}

Konformitas merupakan perubahan perilaku atau kepercayaan menuju norma kelompok sebagai akibat tekanan kelompok. Faktor-faktor yang mempengaruhi konformitas ini meliputi faktor personal dan situasional.

Faktor situasional yang mempengaruhi konformitas meliputi hal-hal sebagai berikut :

a. Kejelasan situasi. Seperti pada penelitian Sherif, semakin tidak jelas dan tidak berstruktur situasi yang dihadapi, semakin besar kecenderungan individu mengikuti kelompoknya.

b. Konteks situasi. Jika kita tahu orang lain akan lebih menyukai kita bila sepakat dengan pendapat dan keyakinan mereka, kita cenderung melakukan konformitas pada kelompok orang lain tersebut di waktu yang akan datang.

c. Cara menyampaikan penilaian. Jika penyampaian respon individu dilakukan secara terbuka, akan cenderung melakukan konformitas daripada jika diungkapkan secara tertutup atau rahasia.

d. Karakteristik sumber pengaruh. 
e. Ukuran kelompok. Semakin besar ukuran kelompok, semakin tinggi tingkat konformitas, hingga ukuran tertentu.

f. Tingkat kesepakatan kelompok (kohesivitas). Semakin tinggi kohesivitas sebuah kelompok, semakin tinggi kecenderungan anggota melakukan konformitas terhadap kelompoknya, dan sebaliknya.

Konformitas juga dipengaruhi oleh faktor personal, sebagai berikut :

a. Usia. Umumnya, semakin tinggi usia seseorang, semakin mandiri dan tidak tergantung pada orang lain maupun kelompoknya, sehingga semakin rendah kecenderungan konformitasnya.

b. Jenis kelamin. Wanita cenderung lebih konformis daripada pria.

c. Stabilitas emosional. Individu yang emosinya kurang stabil lebih mudah mengikuti kelompok daripada individu yang emosinya stabil.

d. Otoritarianisme. Kepribadian otoriter (cenderung etnosentris, ambisa pada kekuasaan, dogmatis, tergantung pada otoritas) berkorelasi positif dengan konformitas.

e. Kecerdasan. Kecerdasan berkorelasi negatif dengan konformitas, artinya semakin tinggi kecerdasan maka semakin rendah kecenderungan konformitas, dan sebaliknya.

f. Motivasi. Motif afiliasi mendorong terjadinya konformitas, sedangkan motif berprestasi, motif 
aktualisasi diri, dan kondep diri yang positif akan menghambat konformitas.

g. Harga diri. Semakin tinggi harga diri seseorang, semakin rendah kecenderunga untuk melakukan konformitas.

\section{Fasilitasi Sosial}

Fasilitasi sosial berkaitan dengan kelancaran atau peningkatan kualitas kerja karena ditonton kelompok. Kelompok mempengaruhi pekerjaan sehingga terasa lebih mudah. Namun, Allport menemukan bahwa fasilitasi sosial tidak selalu memudahkan pekerjaan. Robert Zajonc mencoba menjelaskan dengan teori drive. Menurut teori ini, kehadiran orang lain, menimbulkan efek pembangkit energi pada perilaku individu yang akan meningkatkan munculnya respon dominan. Respon dominan merupakan perilaku yang dikuasai individu.. Jika respon dominan adalah respon yang benar, terjadi peningkatan prestasi, sebaliknya jika respon dominan adalah respon yang salah, terjadi penurunan prestasi.

Apakah fasilitasi sosial terjadi semata-mata karena kehadiran anggota kelompok atau karena merasa dievaluasi oleh kelompok ? Hasil penelitian Cottrell et al. menjelaskan bahwa fasilitasi sosial bisa terjadi karena adanya pengawasan dan penilaian oleh kelompok (Maryam, 2019).

\section{Polarisasi}

Peneliti menyimpulkan bahwa diskusi kelompok cenderung meningkatkan atau melebih-lebihkan 
kecenderungan (preferensi) awal kelompok. Jika sebagian besar anggota kelompok pada awalnya condong ke posisi berisiko pada masalah tertentu, posisi kelompok menjadi lebih berisiko setelah diskusi. Tetapi jika anggota kelompok secara umum pada awalnya condong ke posisi hati-hati, diskusi kelompok mengarah ke kehati-hatian yang lebih besar. Efek ini disebut polarisasi kelompok, yaitu membesar-besarkan kecenderungan awal dalam pemikiran anggota kelompok melalui diskusi kelompok (Moscovici \& Zavalloni, 1969; Myers \& Lamm, 1976; Kassin et al., 2011).

Polarisasi ini memunculkan beberapa implikasi negatif. Pertama, produktivitas dan kreativitas kelompok menurun (terjadi groupthink). Kedua, pada kelompok gerakan sosial atau politik, memicu munculnya perasaan benar sendiri dan menyalahkan kelompok lain (Myers, 2004).

\section{RINGKASAN}

1. Komunikasi kelompok merupakan suatu interaksi antara satu individu dengan individu yang lain dan terjadi aspekaspek psikologis selama proses interaksi tersebut.

2. Kelompok dapat dibedakan menjadi kelompok ingroup dan outgroup. Komunikasi kelompok tentu dapat dijelaskan melalui dua jenis kelompok itu.

3. Adanya komunikasi kelompok membuat individu mudah dalam bersinergi,berkoordinasi, dan melakukan hal-hal yang positif. Komunikasi kelompok juga berpotensi memunculkan terjadinya konflik antar kelompok jika individu yang berada dalam kelompok itu tidak mampu mengelola dinamika yang ada dalam kelompok itu. 
4. Komunikasi kelompok dapat dijelaskan melalui tiga aliran besar psikologi, yaitu psikoanalisis, behaviorisme, dan humanistik. Ketiga aliran itu masing-masing dapat menjelaskan tentang terjadinya proses komunikasi kelompok.

\section{LATIHAN}

1. Uraikan secara singkat penjelasan masing-masing aliran psikologi dalam menjelaskan tentang komunikasi kelompok!

2. Pilihlah sebuah kelompok yang ada di sekitar Anda. Lakukan pengamatan tentang pengaruh kelompok terhadap anggota kelompok. Bagaimana bentuk pengaruh kelompok yang muncul?

\section{DAFTAR PUSTAKA}

Alwisol. (2017). Psikologi Kepribadian. Malang. Penerbit: Umm Press

Barlund, D.C \& F. Halman. (1960). The Dynamics of Discussion, Boston: Houghton-Mifflin

Baron, R.A \& D. Byrne .(1979). Social Psychology: Understanding Human Interaction, Boston: Allyn and bacon, Inc

Byrne, D \& baron, R. (2010). Social Psychology: 10th edition London: Pearson Education

Cooley, C. H. (1909). Social Organization, New York: Scribners Kiesler, C.A \& S.B. Kiesler. (1969). Conformity, reading: Addison-Wesley 
Latipun. (2005). Psikologi Konseling. Malang. Penerbit: Umm Press

Santrock, J.W. (2007). Psikologi Pendidikan.Jakarta. Salemba Sherif,M., O.J. Harvey,B.J. White, W.R. Hood, dan C.W. Sherif. (1961). Intergroup Conflicts and Cooperation: The Robber's Cove Experiment, Norman: University of Oklahoma, Institute of Group Relation 


\section{Bab 6 \\ Komunikasi Massa}

Capaian Pembelajaran Mata Kuliah meliputi :

a. Aspek Sikap dan Tata Nilai :

(1) Bertakwa kepada Tuhan Yang Maha Esa dan mampu menunjukkan sikap religious

(2) Berkontribusi dalam peningkatan mutu kehidupan bermasyarakat, berbangsa, bernegara, dan kemajuan peradaban berdasarkan Pancasila

(3) Menghargai keanekaragaman budaya, pandangan, agama dan kepercayaan serta pendapat atau temuan orisinal orang lain

b. Aspek Ketrampilan Umum :

(1) Menguasai konsep teoritis hubungan manusia dengan lingkungan sosialnya

(2) Menguasai konsep teoritik komunikasi antar pribadi dan komunikasi massa

c. Aspek Ketrampilan Khusus :

Mampu menerapkan pemikiran logis, kritis, sistematis, dan inovatif dalam konteks pengembangan atau implementasi ilmu pengetahuan dan teknologi yang memperhatikan dan menerapkan nilai humaniora

d. Aspek Penguasaan Pengetahuan :

Mampu memahami dan menjelaskan peranan aspekaspek psikologi dalam komunikasi. 
Apakah komunikasi massa itu? Bagaimana komunikasi massa dapat dilihat dan ditangkap oleh jutaan umat manusia di seluruh dunia? Media yang seperti apa yang efektif dalam menyebarluaskan berita sehingga berita itu dapat diterima oleh manusia seluruh dunia? Pertanyaan seperti itu yang sering diajukan dalam memahami konteks komunikasi massa. Komunikasi massa memang dewasa ini sering dibahas dalam berbagai macam ranah, baik dari segi akademisi, ranah pengadilan, ranah politik, bahkan ranah agama. Media massa sering digunakan dalam membuat manusia berubah dalam berpikir, bersikap, dan berperilaku. Banyak ahli berpendapat bahwa proses penyampaian informasi dari komunikator kepada komunikan dalam komunikasi massa terutama pada sisi komunikator. Beberapa ahli menjelaskan bahwa dalam komunikasi massa, yang bertindak sebagai komunikator dapat manusia yang sedang berbicara terhadap sebuah sekumpulan massa atau komunikator dapat juga dilihat dari media yang digunakan untuk melakukan komunikasi. Misalnya ada media cetak yang sedang mengabarkan sebuah berita kepada para pembaca, maka media cetak itu dapat disebut sebagai komunikator (Rahmat, 2005).

Pada bagian ini penulis mencoba mengulas tentang komunikasi massa yang berkaitan dengan efek terhadap psikologis manusia seperti efek kognitif, efek behavior, dan efek afektif dari keberadaan media massa itu sendiri. Pada saat berbicara mengenai efek psikologis, hal yang perlu digarisbawahi adalah bagaimana efek media masa itu mengubah aspek ketiga tersebut. Pertanyaan yang harus 
dilihat adalah seberapa besar dampak perubahan yang ada pada manusia? Apakah perubahan itu baik atau buruk terhadap kondisi keprbadian manusia?

\section{A. Pengertian Komunikasi Massa}

Pada pembahasan di atas dijelaskan bahwa yang bertindak sebagai komunikator adalah manusia yang sedang menyampaikan pesan, tetapi jika dikaji lebih dalam lagi yang termasuk komunikator dalam komunikasi massa adalah media massa atau elektronik yang menyampaikan pesan kepada sejumlah khalayak yang tersebar, heterogen, dan anonim sehingga pesan tersebut dapat diterima secara serentak dan sesaat ( Tan, 1981). Jadi, dapat disimpulkan bahwa komunikasi massa adalah komunikasi yang disampaikan melalui media massa, seperti surat kabar, majalah, radio, televisi, dan film.

Neuman menyatakan bahwa komunikasi massa memiliki empat tanda teknis sekaligus menjadi karakteristik komunikasi massa, sebagai berikut :

1. Bersifat tidak langsung, artinya harus melalui media teknis.

2. Bersifat satu arah, artinya tidak ada interaksi atau timbal balik antara komunikan (media) dengan komunikator.

3. Bersifat terbuka, artinya ditujukan pada publik yang tidak terbatas dan anonim.

4. Mempunyai publik yang secara geografis tersebar.

5. Dikontrol oleh gatekeeper, artinya orang yang berfungsi untuk mengendalikan proses media dari belakang layar. 
Media dpat disebarluaskan dengan konten seperti apa tentu semuanya ada di tangan gatekeeper ini.

Pada penelitian tentang komunikasi massa yang dilakukan oleh Klapper (1960) dalam buku The Effects of Mass Communications, menjelaskan bahwa komunikasi massa selalu terjadi lewat serangkaian faktor-faktor perantara. Perantara ini yang membedakan antara komunikasi massa dengan komunikasi interpersonal, yaitu ada atau tidaknya perantara. Perantara ini yang disebut sebagai media oleh para pakar ahli psikologi massa. Ada kecenderungan manusia memilih media untuk dijadikan sebagai alat komunikasi massa karena media dapat menjangkau beberapa area, diantaranya: 1. Cognition (pemikiran), media digunakan untuk membangkitkan ide. Komunikasi massa terintegrasi dengan kekuatan media massa maupun elektronik. Pemikiran-pemikiran yang matang dan dituangkan dalam media lebih efektif dalam menggerakkan massa.

2. Diversion (diversi), media digunakan untuk memuaskan kebutuhan terutama untuk membangkitkan semangat pada diri manusia setelah sekian lama bekerja. Diversi ini dapat digunakan untuk melakukan komunikasi massa seperti saat ini ada aplikasi zoom atau google meeting untuk melepas lelah dengan teman-teman yang juga sedang melakukan relaksasi. Hal ini dapat memperkuat hubungan personal antar individu melalui media sosial atau aplikasi sosial. 
3. Social utility (kegunaan sosial), media digunakan untuk melakukan kontak dan memperbaiki hubungan dengan teman, keluarga, atau masyarakat.

4. Withdrawl (menarik diri), media digunakan untuk menarik diri dan menjaga privacy supaya tidak diganggu oleh orang lain. Komunikasi massa memang terkadang menjadi mudah bagi manusia dalam banyak hal tetapi bisa juga menjadi masalah bagi individu yang ingin menyendiri. Manusia mampu memanfaatkan komunikasi masa melalui media ini dengan sesuai keadaan dirinya sendiri.

5. Linkage ( pertalian), media dapat menyatukan massa sehingga mampu membentuk suau pertalian atau ikatan yang berdasarkan kepentingan yang sama. Hal ini bisa dilihat pada partai-partai politik saat berkampanye di media cetak mamupun elektronik. Tujuan dari partaipartai itu adalah menarik para calon pemilih dengan persepsi yang sama dari program yang ditawarkan. (Dominick,2002)

\section{B. Faktor-faktor Yang mempengaruhi Reaksi Khalayak pada Komunikasi Massa}

Para peneliti melihat adanya berbagai macam kebutuhan manusia yang berbeda-beda untuk memenuhi kebutuhannya masing-masing. Hal ini dapat dilihat dari reaksi masing-masing individu terhadap suatu media massa yang ditampilkan. Tiap-tiap kelompok sosial telah melakukan respon yang berbeda-beda dalam menyikapi media massa. Banyak faktor yang mempengaruhi tiap-tiap kelompok sosial 
dalam merespon media massa. Faktor-faktor ini meliputi biologis, sikap, nilai, kepercayaan, serta pengalaman. Pada proses ini, kelompok-kelompok sosial menjadi anggota dan hubungan-hubungan interpersonal pada proses penerimaan, pengelolaan, dan penyampaian informasi. Pada kelompok sosial seperti eksekutif perusahaan atau pengusaha labih menyukai dan merespon media masa yang bersifat rubrik niaga sementara orang yang berada di daerah pedesaan lebih menyukai bacaan koran tradisional seperti jawa pos atau kedaukatan rakyat.

Kelompok-kelompok sosial yang berbeda dalam merespon media massa ini, akan mengantarkan pada pembahasan uses and gratifications. Apa yang dibahas dalam uses and gratifications? Katz, Blumler, dan Guretvitch (1974) menjelaskan bahwa uses and gratifications merupakan kebutuhan secara psikologis dan sosial, yang menimbulkan harapan tertentu dari media massa atau sumber-sumber lain, yang membawa pada pola terpaan media yang berlainan, dan menimbulkan pemenuhan kebutuhan dan akibat-akibat lain, termasuk juga yang tidak kita inginkan. Teori ini memiliki asumsi-asumsi dasar seperti:

1. Khalayak dianggap aktif, artinya sebagian penting dari penggunaan media massa diasumsikan mempunyai tujuan.

2. Komunikasi massa mengaitkan pada pemuasan kebutuhan dengan pemilihan media pada khalayak.

3. Media massa harus bersaing dengan sumber-sumber lain untuk memuaskan kebutuhan khalayak, agar dapat 
diterima oleh khalayak umum. Kebutuhan ini terpenuhi melalui konsumsi media yang bergantung pada perilaku khalayak yang bersangkutan.

4. Penilaian tentang arti kultural dari media massa harus ditangguhkan sebelum diteliti lebih dahulu orientasi khalayak.

Teori uses and gratifications ini memang cukup berbeda jika dikaitkan dengan teori komunikasi yang lain. Pada kebanyakan teori komunikasi, bahwa fokus pembahasannya adalah mengenai teori bagaimana individu mengirimkan pesan. Pada teori ini, pembahasan lebih ditekankan pada bagaimana penerimaan pesan. Penerimaan pesan yang dimaksud di sini adalah bagaimana individu memiliki motif sendiri dalam memilih media massa yang sedang ditampilkan. Manusia memiliki pilihan untuk memenuhi kebutuhannya melalui komunikasi massa. Pada buku ini akan dijelaskan lebih dalam mengenai kerangka psikologis dari uses and gratifications. Kerangka psikologis itu akan membahas tentang bagaimana konsumsi komunikasi massa merupakan perlaku yang didorong oleh motif-motif tertentu. Banyak orang berpendapat bahwa faktor media terutama media massa merupakan faktor eksternal dalam mempengaruhi perilaku manusia ( McGuire, 1974). Komunikasi massa tidak hanya melihat dari sisi pengaruh eksternal, tetapi harus dapat dijelaskan pada tataran psikologis yang dapat mempengaruhi perilaku manusia dan memenuhi kebutuhan manusia. Psikologi komunikasi massa 
berusaha menguak dan mengidentifikasi segala hal-hal yang tersembunyi dari manusia terkait dengan motif-motif dalam memilih media yang dapat memenuhi kebutuhannya.

McGuire menjelaskan ada dua motif yang menyebabkan kita bereaksi terhadap media massa dengan cara yang berbeda.Dua motif itu adalah motif kognitif dan motif gratifikasi media. Dua motif ini dapat dipecah lagi menjadi beberapa poin untuk menjelaskan perbedaan bereaksi manusia pada media massa.

\section{Motif Kognitif}

a) Teori konsistensi, menekankan bagaimana manusia dalam merespon media massa dengan selektif sesuai dengan kebutuhannya. Media massa yang cukup masif dalam memberitakan sesuatu tentu harus diseimbangkan dengan kebutuhan manusia yang menangkap pesan itu.

b) Teori atribusi, menekankan bagaimana manusia dalam merespon suatu peristiwa. Hal ini tentu manusia akan melakukan berbagai macam pertimbangan-pertimbangan dalam memahami suatu peristiwa yang ada sebelum dapat melakukan interpretasi terhadap suatu peristiwa itu.

c) Teori kategorisasi, menekankan pada upaya manusia dalam memberikan makna tentang dunia berdasarkan kategori-kategori internal yang ada dalam dirinya. Pesan dari komunikasi massa dengan mudah dibangun melalui kategori-kategori yang ada dalam diri kita. 
d) Teori objektifikasi, menekankan peran manusia dalam memberikan makna terhadap dunia eksternal. Hal ini kebalikan dari teori kategorisasi, dimana manusia mengambil kesimpulan dari pesan media tentang perilaku-perilaku yang tampak.

\section{Motif Gratifikasi}

a) Teori reduksi tegangan, melihat bahwa manusia sebagai sistem berusaha untuk mengurangi tegangantegangan yang ada yang terjadi dalam berbagai macam peristiwa termasuk peristiwa yang ditampilkan oleh media masssa. Media masa sering menampilkan peristiwa-peristiwa yang destruktif dan fungsi manusia adalah untuk mengurangi efek dari tayangan kekerasan ini.

b) Teori ekspresif, menekankan bahwa manusia mampu memperoleh kepuasan dengan menampakkan perasaannya melalui identifikasi tokoh-tokoh yang ditampilkan di media massa. Hal ini sesuai dengan teori Freud dalam hal defense mechanism, tentang cara manusia dalam mengurangi kecemasannya terhadap suatu peristiwa.

c) Teori ego-defensif, menekankan bahwa manusia berusaha dalam membangun citra diri yang ideal yang sesuai dengan dirinya dan dunia luar. Komunikasi dan media massa membuat individu mampu memperkokoh konsep diri dan membantu melakukan pertahanan ego. Teori ini menggambarkan dua teori sekaligus yaitu Maslow (gambaran dunia nyata dan 
dirinya) dan Freud tentang mekanisme pertahanan diri. Komunikasi massa melalui media memang dapat mengubah kepribadian manusia tergantung bagaimana manusia merespon dan bersikap terhadap hal itu. Media yang menampilkan public figure dapat membuat manusia melakukan berbagai perilaku, seperti melakukan objekifikasi, berfantasi, menemukan konsep dirinya dan masih banyak lagi.

d) Teori peneguhan, teori ini memandang individu dalam situasi tertentu yang akan membawa pada perilaku yang mendapatkan ganjaran. Teori ini selaras dengan madzhab behaviorisme, tentang proses mendapatkan reward dan punishment. Teori ini didukung dengan jelas oleh penelitian yang dilakukan oleh Subiakto (2015) yang menyatakan bahwa politik tidak bia dipisahkan dengan hal-hal yang berupa reward dan punishment. Janji-janji saat kampanye menjadi santapan bagi politisi yang akan maju dalam pemilihan suatu kepala daerah. Semakin banyak warga atau massa yang yakin dengan janji itu, maka semakin intens juga politisi tersebut dalam melakukan kampanye di wilayah itu.

\section{Efek Komunikasi Massa}

Manusia yang memilih media sebagai alat untuk melakukan komunikasi massa tentu telah mempertimbangkan secara matang konsekuensi apa yang akan terjadi pada dirinya. Konsekueni itu yang nanti akan menjad sebuah efek dari media massa itu sendiri. Pada pembahasan di atas sudah 
dijelaskan bahwa ada tiga efek dalam komunikasi massa, sebagai berikut :

1. Efek kognitif, meliputi pembentukan dan perubahan citra, serta agenda setting. Citra terbentuk berdasarkan informasi yang diterima individu. Media massa bekerja untuk menyampaikan informasi ini. Informasi ini dapat membentuk, mempertahankan, atau mendefinisikan citra. Pembentukan citra ini biasanya diikuti oleh perubahan perilaku. Media massa juga membawa efek pada perubahan agenda kegiatan individu (agenda setting).

2. Efek afektif, meliputi pembentukan dan perubahan sikap, rangsangan emosional, serta rangsangan seksual.

3. Efek behavioral, meliputi efek prososial perilaku, agresi, dan efek sosial.

Efek yang dijelaskan di atas memang semakin sering muncul seiring dengan perkembangan teknologi. Perkembang teknologi sangat mempengaruhi tingkat efek pada tiga aspek psikologis pada manusia. Media massa seperti televisi, gadget, dan media sosial menjadi tumpuan untuk menjadi ajang aktualisasi diri. Faktanya media massa telah menjadi proses aktualisasi diri pada manusia, menurut Abraham Maslow. Manusia menganggap bahwa dengan menguasai teknologi maka merasa menjadi manusia yang positif. Hal itu karena individu yang telah menguasai gadget atau media massa, sudah melewati tahapan-tahapan dalam mengaktualisasikan dirinya mulai dari kebutuhan fisiologis, rasa aman, rasa cinta, dan harga diri. 
Perkembangan manusia dalam menerima informasi dari media massa tentu sangat dipertimbangkan. Perkembangan yang matang identik dengan berbagai macam kematangan yang dimiliki oleh individu itu termasuk ketika menerima informasi dari media massa ( Santrock, 2007). Komunikasi dapat dibentuk secara efektif sesuai dengan perkembangan dirinya. Komunikasi disini bukan hanya sebagai komunikator saja tetapi sebagai komunikan terhadap media massa yang diterimanya ( Hermoyo, 2015). Proses komunikasi yang terjadi melalui sensori dan memori memang memerlukan kematangan intelektual dan emosional untuk menerima informasi seperti itu.

Jadi dapat kita simpulkan bahwa komunikasi massa itu bukanlah komunikasi seperti seorang pemimpin negara yang sedang berpidato di depan rakyatnya tetapi komunikasi massa adalah komunikasi melalui perantara atau media untuk menyebarluaskan berita yang telah dikemas sedemikian rupa agar bisa dinikmati oleh banyak orang. Komunikasi massa merupakan komunikasi yang tidak langsung dan mampu menembus banyak wilayah. Hal ini diperkuat dengan keadaan saat ini dimana terdapat jaringan internet yang luas dan bisa diakses oleh siapapun.

\section{RINGKASAN}

Komunikasi massa merupakan proses komunikasi yang dimulai dari media maSsa sebagai instrumen penyampaian pesan kepada khalayak atau masyarakat. Media massa beragam bentuknya, mulai dari televisi, media cetak maupun media sosial. Ketiga instrumen media ini menjadi 
sarana komunikasi bagi komunikator terhadap komunikan. Media massa mampu memberikan dampak secara masif terhadap aspek psikologi manusia, mencakup aspek kognitif, afektif, dan behavior .

\section{LATIHAN}

1. Mengapa media sosial memiliki pengaruh yang besar dalam mengubah perilaku manusia?

2. Carilah sebuah bentuk komunikasi massa di media massa. Jelaskan efek yang ditimbulkan dari komunikasi massa tersebut!

\section{DAFTAR PUSTAKA}

Dominick, Joseph R (2002). The Dynamic Mass Communication: Media in The Digital Age 7 th Edition. New York: The McGraw-Hill Companies

Kartz, E., J.G. Blumler \& M. Gurevitch. (1974). " Utilization of Mass Communication by Individual", The Uses of Mass Communication Correct Perspective on Gratification Research, J.G. Blumerand E. Katz, editors, London, Beverly Hills: :Sage Publication

Kiesler, C.A \& S.B. Kiesler. (1969). Conformity, reading: Addison-Wesley

Klapper, J.T. (1960). The Effects of Mass Communication, Illinois: free Press

Maulana, H \& Gumelar, G. (2013). Psikologi Komunikasi dan Persuasi. Jakarta. Penerbit: Akademia Permata

Mc Guire, W.J. (1974). "Psychological Motivates and Communication Gratification", The Uses of Mass 
Communication, J.G. Blumler dan E. Katz, editors, beverly Hills: Sage Publications

Rahmat, J, (2005). Psikologi Komunikasi. Bandung: PT Remaja Rosdakarya 


\section{BAB 7 \\ KOMUNIKASI VERBAL dan NON VERBAL}

Capaian Pembelajaran Mata Kuliah meliputi :

a. Aspek Sikap dan Tata Nilai :

(1) Bertakwa kepada Tuhan Yang Maha Esa dan mampu menunjukkan sikap religious

(2) Berkontribusi dalam peningkatan mutu kehidupan bermasyarakat, berbangsa, bernegara, dan kemajuan peradaban berdasarkan Pancasila

(3) Menghargai keanekaragaman budaya, pandangan, agama dan kepercayaan serta pendapat atau temuan orisinal orang lain

b. Aspek Ketrampilan Umum :

(1) Menguasai konsep teoritis hubungan manusia dengan lingkungan sosialnya

(2) Menguasai konsep teoritik komunikasi antar pribadi dan komunikasi massa

c. Aspek Ketrampilan Khusus :

Mampu menerapkan pemikiran logis, kritis, sistematis, dan inovatif dalam konteks pengembangan atau implementasi ilmu pengetahuan dan teknologi yang memperhatikan dan menerapkan nilai humaniora

d. Aspek Penguasaan Pengetahuan :

Mampu memahami dan menjelaskan peranan aspekaspek psikologi dalam proses komunikasi. 
Komunikasi merupakan sarana untuk menyampaikan pesan atau menerjemahkan gagasan individu dalam bentuk lambang, baik menggunakan kata-kata (secara verbal) maupun bahasa tubuh (secara non verbal). Bab ini membahas tentang komunikasi verbal maupun non verbal dalam komunikasi manusia.

\section{A. Komunikasi Verbal}

Komunikasi verbal dalam proses komunikasi berkaitan dengan kata dan makna. Proses komunikasi merupakan pengiriman pesan dari sistem syaraf seseorang kepada sistem syaraf orang lain, untuk menghasilkan makna yang serupa dengan yang ada dalam pikiran pengirim pesan (Maulana \& Gumelar, 2013). Komunikasi verbal melakukan pengiriman pesan tersebut melalui kata-kata. Dalam kehidupan bersosial seringkali terjadi konflik karena setiap orang memberikan makna yang berbeda pada satu kata. Rakhmat (2011) menegaskan, bahwa "Kata-kata tidak bermakna, oranglah yang memberikan makna."

Apa yang disebut dengan makna ? Menurut psikologi, makna tidak terletak pada kata-kata, namun tergantung pada pikiran orang atau persepsi. Makna terbentuk karena pengalaman individu. Karena pengalaman hidup masingmasing individu berbeda, maka masing-masing orang memiliki makna tersendiri untuk kata-kata tertentu. Hal ini disebut makna perorangan (rakhmat, 2011).

Tidak selamanya makna itu bersifat perorangan. Terdapat juga makna yang dimiliki bersama oleh sebagian orang dalam sebuah kelompok. Kesamaan makna karena 
kesamaan pengalaman masa lalu atau kesamaan struktur kognitif disebut isomorfisme (Rakhmat, 2011). Isomorfisme terjadi jika komunikasi berasal dari budaya yang sama, status sosial sama, pendidikan sama, ideology sama, dan sebagainya. Namun, kenyataannya tidak pernah ada isomorfisme secara total, selalu ada makna perorangan.

Orang-orang dalam kelompok yang sama, seringkali mengembangkan kata-kata yang dimiliki secara khusus oleh kelompoknya saja. Misalnya, setiap bidang profesi memiliki kata-kata khusus yang hanya dipahami oleh kelompok profesi tertentu.

\section{B. Bahasa}

\section{Pengertian Bahasa}

Apakah bahasa itu ? Bahasa bisa didefinisikan melalui dua cara, yaitu fungsional dan formal. Secara fungsional, bahasa diartikan dari segi fungsinya, yaitu sebagai alat yang dimiliki bersama untuk mengungkapkan gagasan (socially shared means for expressing ideas). Definisi ini menekankan socially shared, karena bahasa hanya dapat dipahami jika terdapat kesepakatan di antara anggota kelompok sosial untuk menggunakannya (Rakhmat, 2011).

Bahasa secara formal diartikan sebagai semua kalimat yang terbayangkan, yang dapat dibuat menurut peraturan tata bahasa. Setiap bahasa memiliki peraturan bagaimana kata-kata harus disusun dan dirangkai agar memiliki arti. Tata bahasa memiliki tiga unsur, yaitu fonologi, sintaksis, dan semantik. Fonologi terkait bunyi-bunyi dalam sebuah bahasa (misalnya dalam bahasa Jawa, kata "alon-alon" yang berarti 
pelan-pelan dan "alon-alon" yang berarti alun-alun), sintaksis berkaitan dengan cara pembentukan kalimat, sedangkan semantik merupakan leksikal arti kata atau gabungan katakata. Menurut Miller, agar mampu menggunakan bahasa tertentu, kita harus menguasai ketiga unsur di atas, ditambah dua unsur lagi, yaitu kerangka konseptual atau pengetahuan konseptual dan sistem kepercayaan untuk menilai hal-hal yang kita dengar (Rakhmat, 2011). Dua unsur yang terkahir inilah yang menjadi fokus kajian psikologi.

\section{Bagaimana Manusia Bisa Berbahasa ?}

Seorang anak kecil mampu berbahasa Indonesia dengan tata bahasa Indonesia, padahal ia belum dikursuskan bahasa Indonesia. Bagaimana ia mampu melakukan hal itu ? Menurut perspektif psikologi, kemampuan berbahasa manusia bisa dijelaskan oleh teori belajar (behaviorisme) dan teori nativistik yang dipopulerkan Noam Chomsky.

Menurut teori belajar, anak-anak memperoleh pengetahuan bahasa melalui tiga proses, yaitu asosiasi, imitasi, dan peneguhan. Asosiasi berarti melazimkan suatu bunyi dengan objek tertentu. Imitasi artinya menirukan orang lain dalam mengucapkan dan menggunakan struktur kalimat. Sedangkan peneguhan diartikan sebagai ganjaran atau hadiah yang diberikan kepada anak ketika mengucapkan kata-kata dengan tepat.

Pandangan teori belajar berbeda dengan pandangan teori nativistik. Menurut Chomsky, setiap anak mampu menggunakan sebuah bahasa karena faktor bawaan yang terprogram secara genetik dalam otak. Adanya faktor 
fisiologis terkait kemampuan berbahasa pada manusia dibuktikan dengan penemuan area broca dan wernicke pada otak manusia. Area brocka mengatur sintaksis, sehingga ketika terjadi gangguan pada area ini menyebabkan orang berbicara terpatah-patah dengan susunan kata yang tidak teratur. Sementara itu, kerusakan pada area wernicke menyebabkan orang berbicara lancar namun tidak memiliki arti (Rakhmat, 2011). Jean Piaget memperkuat pandangan Chomsky, bahwa otak manusia bukanlah penerima pengalaman yang pasif, namun telah dilengkapi dengan kemampuan-kemampuan bawaan.

Pandangan kedua aliran di atas sama-sama memiliki kebenaran. Menurut Blount, pada dasarnya kemampuan bahasa manusia merupakan proses interaksi antara faktor biologis dan hasil belajar dari interaksi dengan lingkungan (Rakhmat, 2011).

\section{Bahasa dan Berpikir}

Berpikir diartikan sebagai upaya memanipulasi informasi secara mental, seperti membentuk konsep-konsep abstrak, menyelesaikan masalah, mengambil keputusan, dan menghasilkan gagasan kreatif (King, 2012). Konsep sebagai salah satu aspek mendasar dalam berpikir merupakan kategori-kategori mental yang digunakan untuk mengelompokkan objek, kejadian, dan sifat. Misalnya, apel dan jeruk termasuk buah.

Whorf menjelaskan bahwa gramatikal sebuah bahasa menunjukkan kategori kognitif dari pemakai bahasa tersebut. Proses persepsi pun dilakukan menggunakan kognitif. Kita 
memberikan arti kepada apa yang kita lihat, dengar, atau rasakan sesuai kategori yang ada dalam bahasa kita (Rakhmat, 2011).

Bahasa memungkinkan manusia melakukan penyandian (coding) terhadap peristiwa dan objek dalam bentuk kata-kata. Melalui bahasa individu mampu mengabstraksikan pengalaman dan mengkomunikasikan kepada orang lain. Sebaliknya, bahasa merupakan sistem lambang yang mampu mengungkapkan berbagai macam pemikiran. Dengan bahasa, manusia mengkomunikasikan pemikirannya kepada orang lain dan menerima satu sama lain terkait pemikirannya. Rakhmat berpendapat bahwa "Memang betul kita tidak selalu berpikir dengan kata-kata, namun sedikit sekali kita dapat berpikir tanpa kata-kata."

\section{Komunikasi Nonverbal}

Pernahkan kita berada dalam sebuah situasi dimana kita berusaha untuk berkomunikasi tanpa menggunakan katakata ? Barangkali kita juga pernah berinteraksi dengan orang yang tidak bisa mendengarkan, atau dengan seseorang yang jaraknya terlalu jauh untuk bisa mendengarkan apa yang Anda bicarakan. Meskipun tanpa menggunakan kata-kata, kita bisa menyimpulkan tentang pesan seseorang dan keadaan emosinya. Kita bisa menginterpretasikannya melalui komunikasi nonverbal yang ditunjukkan mereka. Menurut DePaulo, perilaku nonverbal relatif tidak bisa dikekang atau sulit untuk dikontrol, sehingga saat seseorang mencoba menyembunyikan perasaan yang sesungguhnya dari orang 
lain, perilaku itu tetap tampil melalui isyarat-isyarat nonverbal (Baron \& Byrne, 2003).

Penting untuk diingat, bahwa petunjuk nonverbal yang ditampilkan seseorang dapat mempengaruhi perasaan kita meskipun kita tidak secara sadar memperhatikan petunjuk tersebut, ataupun sengaja mencoba membaca perasaannya. Misalnya, ketika kita bertemu dengan teman yang menampilkan ekspresi wajah marah dan tekanan suara tinggi, kita juga bisa secara tiba-tiba mengekspresikan wajah marah dan tekanan suara kita juga tinggi. Komunikasi nonverbal memiliki efek penularan emosional. Sebagaimana hasil penelitian Neumann dan Strack (2000) menemukan bahwa ketika seseorang mendengarkan orang lain berpidato, nada suara pembicaranya (senang, sedih, netral) bisa mempengaruhi perasaan pendengar meskipun sebenarnya pendengar fokus pada isi pidato, bukan pada keadaan emosional pembicara. Gejala ini disebut oleh Baron dan Byrne dengan penularan emosional (emotional contagion), yaitu mekanisme yang mentransfer perasaan secara otomatis dari satu orang ke orang lain (Maryam, 2018).

\section{Tipe-tipe atau Saluran Komunikasi Nonverbal}

Menurut Delamater dan Myers (2011), terdapat empat tipe atau saluran komunikasi nonverbal, yaitu sebagai berikut :

\section{Paralanguage}

Merupakan semua aspek vokal dalam berbicara selain kata-kata, perilaku dalam bentuk vokal atau variasi ucapan, seperti kerasnya suara, kecepatan berbicara, jeda 
dalam berbicara, nada suara, tekanan suara, nafas, dan sebagainya. Isyarat paralinguistik diterima melalui pendengaran (auditori).

\section{Bodylanguage atau kinesics (kinesik)}

Yakni gerakan diam dari anggota tubuh, seperti gestur (gesture), ekspresi wajah (facial expression), tatapan mata (eye gaze), gerakan kaki, anggukan, pergeseran postur, jabat tangan, sentuhan, dan sebagainya. Isyarat kinesik diterima melalui visual.

\section{Interpersonal spacing atau proxemics (proksemik)}

Merupakan posisi diri kita pada jarak dan sudut dari orang lain, seperti jarak berdiri dekat atau jauh, posisi menghadap kepala, menggunakan penghambat jarak dengan buku atau objek lain, dan sebagainya. Secara umum, semakin akrab seseorang dengan orang lain, semakin dekat jaraknya dalam berinteraksi. Kita cenderung menjaga jarak untuk menunjukkan ketidaktertarikan atau ketidaksukaan kita.

4. Aspek-aspek personal lainnya yang sengaja dipilih atau diciptakan individu, seperti pilihan pakaian, gaya rambut, makeup, contact lense, parfum, dan sebagainya.

\section{RINGKASAN}

1. Komunikasi merupakan sarana untuk menyampaikan pesan atau menerjemahkan gagasan individu dalam bentuk lambang, baik menggunakan kata-kata (secara verbal) maupun bahasa tubuh (secara non verbal).

2. Bahasa memungkinkan manusia melakukan penyandian (coding) terhadap peristiwa dan objek dalam bentuk kata- 
kata. Melalui bahasa individu mampu mengabstraksikan pengalaman dan mengkomunikasikan kepada orang lain. Sebaliknya, bahasa merupakan sistem lambang yang mampu mengungkapkan berbagai macam pemikiran.

\section{LATIHAN}

1. Komunikasi yang dilakukan sesorang tidak hanya berbentuk verbal namun juga nonverbal. Mengapa komunikasi nonverbal diperlukan dalam berkomunikasi ?

2. Apakah komunikasi nonverbal komunikator mampu mempengaruhi sikap dan perilaku komunikan ? Jelaskan!

3. Amati video pidato, kampanye atau motivasi. Apa saja bentuk komunikasi nonverbal yang digunakan dan apa tujuan komunikasi nonverbal yang dilakukan tersebut?

\section{DAFTAR PUSTAKA}

Baron, R.A., dan Byrne, D., 2003. Psikologi Sosial Jilid 1. Edisi Kesepuluh. Erlangga, Jakarta.

Delamater, John D. dan Myers, Daniel J. 2011. Social Psychology Seventh Edition. Wadsworth Cengage Learning, USA.

King, Laura A. 2012. Psikologi Umum, Sebuah Pandangan Apresiasif, Buku 1. Terjemahan. Jakarta : Salemba Humanika.

Maulana, Herdiyan dan Gumelar, Gumgum. 2013. Psikologi Komunikasi dan Persuasi. Jakarta : Akademia Permata.

Maryam, Effy W. 2018. Buku Ajar Psikologi Sosial. Sidoarjo : UMSIDA Press. 
Rakhmat, Jalaluddin. 2011. Psikologi Komunikasi, Cetakan Ke27. Bandung : Remaja Rosdakarya. 


\section{BAB 8 \\ KOMUNIKASI PERSUASIF}

Capaian Pembelajaran Mata Kuliah meliputi :

a. Aspek Sikap dan Tata Nilai :

(1) Bertakwa kepada Tuhan Yang Maha Esa dan mampu menunjukkan sikap religious

(2) Berkontribusi dalam peningkatan mutu kehidupan bermasyarakat, berbangsa, bernegara, dan kemajuan peradaban berdasarkan Pancasila

(3) Menghargai keanekaragaman budaya, pandangan, agama dan kepercayaan serta pendapat atau temuan orisinal orang lain

b. Aspek Ketrampilan Umum :

(1) Menguasai konsep teoritis hubungan manusia dengan lingkungan sosialnya

(2) Menguasai konsep teoritik komunikasi antar pribadi dan komunikasi massa

c. Aspek Ketrampilan Khusus :

Mampu menerapkan pemikiran logis, kritis, sistematis, dan inovatif dalam konteks pengembangan atau implementasi ilmu pengetahuan dan teknologi yang memperhatikan dan menerapkan nilai humaniora

d. Aspek Penguasaan Pengetahuan :

Mampu memahami dan menjelaskan peranan aspekaspek psikologi dalam proses komunikasi. 
Pada proses komunikasi kelompok dan komunikasi massa, akan terjadi dinamika proses komunikasi yang kompleks, melibatkan aspek kognitif dan aspek emosional. Proses komunikasi yang melibatkan aspek kognitif dan emosional itu dalam bahasa komunikasi disebut dengan komunikasi persuasif. Apa yang disebut dengan komunikasi persuasif? Apa saja elemen-elemen dalam komunikasi persuasive ? Bidang-bidang apa saja yang sering menggnakan komunikasi persuasive untuk menyampaikan pesannya ? Bagaimana teknik-teknik komunikasi persuasive ? Bab ini akan menjawab pertanyaan-pertanyaan tersebut.

\section{A. Pengertian Komunikasi Persuasif}

Persuasi berasal dari bahasa latin yaitu persuasio, yang artinya mengajak, membujuk, atau merayu. Proses komunikasi persuasif ini tentu melibatkan komunikator (penyampai pesan) terhadap komunikan (penerima pesan). Proses komunikasi persuasi dapat dikatakan berhasil apabila komunikator dapat mempengaruhi komunikan dan dampak panjangnya adalah terjadinya perubahan sikap dan perilaku pada diri komunikan. Pertanyaan yang muncul seputar materi komunikasi persuasif adalah bagaimana melakukan persuasi yang tepat? Apa pesan yang akan disampaikan ketika melakukan persuasi? Untuk menjawab pertanyaanpertanyaan diatas, Burton \& Huffner (2002) menjelaskan tiga jenis pola komunikasi, meliputi :

1. Komunikasi asertif, yaitu kemampuan komunikasi yang dilakukan tanpa menyinggung perasaan orang lain baik 
secara verbal maupun nonverbal dan pesan itu disampaikan secara lugas.

2. Komunikasi pasif, yaitu pola komunikasi yang tidak mempunyai umpan balik sehingga bisa dikatakan komunikasi itu tidak efektif.

3. Komunikasi agresif, yaitu pola komunikasi yang disampaikan dengan tegas dan lugas tetapi disertai dengan kekerasan baik verbal maupun nonverbal.

Fakta di lapangan menunjukkan, ketika proses komunikasi persuasif terjadi, komunikasi agresif jarang sekali digunakan untuk melakukan tindakan persuasif atau membujuk orang lain dalam merubah perilakunya. Pola komunikasi pasif dan asertif menjadi pola yang sering digunakan dalam komunikasi sehari-hari.

Proses komunikasi persuasif dapat dilakukan melalui tatap muka langsung maupun tidak langsung seperti melalui media massa. Contoh yang paling nyata adalah komunikasi persuasif seperti penayangan iklan. Iklan dinilai sarana yang sangat tepat dalam melakukan proses komunikasi persuasif. Iklan dianggap dapat mempengaruhi aspek kognitif dan emosional pada diri manusia. Iklan yang berisi perkenalan produk-produk biasanya memiliki sebuah komunikasi melalui simbol yang berisi ajakan untuk membeli produk tersebut. Hal itu termasuk komunikasi persuasif yang dilakukan media terhadap massa. 


\section{B. Elemen-elemen Komunikasi Persuasif}

Komunikasi persuasif memiliki beberapa elemen untuk dapat mempengaruhi individu atau sekelompok masyarakat, yaitu

1. Claim, yaitu pernyataan tujuan persuasi baik yang tersurat maupun tersirat. Misalnya dalam iklan rokok, secara lugas iklan itu mengajak terang-terangan untuk membeli rokok kepada masyarakat (eksplisit) tetapi karena iklan rokok tidak boleh terlalu vulgar dalam mengajak masyarakat membeli rokok maka iklan rokok pun dibuat secara tertutup tetapi tidak meninggalkan substansinya mengajak masyarakat dalam membeli rokok (implisit).

2. Warrant, yaitu ajakan yang dibungkus dengan kata-kata yang cenderung tidak memaksa. Misalnya ada sebuah ajakan yang berbunyi, " Mari kita bersama-sama menjaga lingkungan kita." Kalimat itu secara tidak langsung mengajak dengan cara yang halus tetapi bersifat perintah.

3. Data, yaitu dalam melakukan ajakan terhadap massa, komunikator biasanya menggunakan data-data sebagai pijakan dalam melakukan ajakan. Misalnya, iklan membeli minuman $X$ disertai data yang berbunyi "menurut penelitian yang dilakukan oleh lembaga $x$ menyatakan bahwa 9 dari 10 berapa persen manusia di dunia mengnsumsi minuman $x$ tersebut". Hal itu akan menambah yakin para komunikan atau masyarakat yang melihat iklan tersebut untuk dapat membeli produk itu terutama di kalangan menengah ke atas dan kalangan intelektual atau akademis. Kalangan ini biasanya akan percaya dengan sesuatu yang bersifat by data untuk 
melakukan sesuatu termasuk membeli produk sesuatu agar lebih yakin dengan produk yang dibelinya.

\section{Faktor Penentu Komunikasi Persuasif}

Persuasi intinya merupakan proses psikologis yang digunakan untuk mempengaruhi sikap, sifat, perilaku, dan pendapat dari orang lain (Seiter dkk, 2010). Ketika manusia mampu melakukan persuasi yang baik, tentu manusia akan mudah dalam mencapai apapun dari goals atau tujuan-tujuan yang diharapkan, baik itu bersifat baik maupun buruk. Individu yang mampu melakukan persuasi, maka dia mampu melakukan sebuah kegiatan yang dapat menggerakkan massa. Seorang provokator ketika dia memiliki persuasi yang baik, maka dia mampu melakukan membuat orang lain mengikutinya untuk menjadi provokator. Seorang aktivis yang akan melakukan makar terhadap suatu pemerintahan yang sah dan memiliki persuasi yang baik, maka dia akan mampu menggerakkan suatu massa untuk menjatuhkan pemerintahan sah. Individu yang memiliki keilmuan agama mendalam atau seorang ustadz dan memiliki persuasi yang baik, tidak jarang individu itu mampu menyadarkan banyak orang untuk dapat hijrah ke jalan yang benar. Jadi, jelas bahwa segala bentuk persuasi tidak hanya dapat dilihat dari proses penyampaian pesan saja tetapi pengaruh atau figur dari komunikator itu yang juga dapat membantu tercapainya proses persuasi yang efektif. Proses persuasi juga dapat disebut dengan social influence, proses terjadinya pengaruh sikap dan prilaku dari individu yang menyampaikan pesan dengan adanya tujuan-tujuan tertentu. 
Kassin, et. al., (2008) mendeskripsikan tiga faktor penting yang mempengaruhi komunikasi persuasif, meliputi faktor yang berasal dari komunikator, komunikan, dan pesan yang disampaikan. Berikut penjelasan masing-masing factor tersebut :

\section{Faktor yang berasal dari komunikan}

Persuasi pada dasarnya dimulai dari adanya kebutuhan, keinginan, dorongan jiwa, dan motivasi. Keempat hal tersebut merupakan drive (penggerak) bagi manusia untuk melakukan proses persuasi.

a. Kebutuhan : proses persuasi yang harus didahului dengan kebutuhan individu itu sendiri. Kebutuhan individu itu sangat beragam, namun yang pokok menurut Maslow, kebutuhan dasar manusia ada pada sandang, pangan, dan papan. Needs ini menjadi sesuatu yang tidak bisa dipisahkan dari individu ketika akan melakukan persuasi.

b. Keinginan. Setelah kebutuhan dipenuhi, muncul adanya wants atau keinginan dari individu untuk segera dipenuhi kebutuhan itu. Pada konteks psikologis, keinginan itu tidak selalu baik, ada juga keinginan yang buruk. Freud menjelaskan bahwa keinginan itu justru sangat dipenuhi oleh nafsu-nafsu yag destruktif. Hal ini yang membuat manusia harus mempertimbangkan betul secara baik tentang keninginan ini. Keinginan yang baik tentu harus sesuai dengan kebutuhan yang baik juga.

c. Dorongan jiwa. Dorongan ini satu tingkat lebih tinggi dari keinginan. Jka keinginan lebih kepada motif 
individu akan melakukan sesuatu, maka dorongan jiwa lebih kepada individu untuk mengendalikan jiwanya dalam melakukan sesuatu. Dorongan jiwa lebih menekankan adanya dinamika kepribadian untukmencapai segala kebutuhan dasar yang ada.

d. Motivasi. Motivasi merupakan sesuatu yang tampak dari individu untuk melakukan segala aktivitasnya termasuk proses persuasi. Individu yang melakukan proses persuasi dapat dilihat dari motivasi internal dan motivasi eksternal. Beragam motivasi yang ada pada diri individu, maka jenis persuasi yang dilakukan juga beragam. Motivasi disini sudah masuk dalam ranah kehendak bagi manusia untuk melakukan sesuatu.

Keempat hal itu menjadi dasar pertimbangan bagi individu untuk melakukan persuasi dan jika keempat itu tidak mampu berjalan dengan baik, maka akan didapatkan hambatan-hambatan komunikasi seperti noise factor, semantic factor, interest, motif, dan prasangka (prejudice).

\section{Faktor yang Berasal dari Komunikator}

Strategi persuasi pada keilmuan psikologi memang selalu dipusatkan pada faktor emosional dan kognitif pada diri manusia. Esensinya sangat mudah, bahwa faktor kognitif dan emosional merupakan faktor yang menggerakkan perilaku sehingga proses persuasi dari komunikator ke penerima pesan (komunikan) selalu diarahkan pada variabel-variabel kognitif seperti memori, 
persepsi, mindset dan emosional seperti perasaan, sikap, dan kedewasaan. Pembahasan mengenai psikologi persuasi ditulis oleh Robert Cialdini yang berjudul "Psychology of Persuasion" yang menjelaskan beberapa aspek dalam proses persuasi, meliputi :

a. Reciprocity

Proses persuasi ini merupakan proses persuasi timbal balik dari dua individu atau masyarakat bahkan negara, yang saling mempengaruhi dengan cara yang saling menguntungkan. Misalnya bagaimana hubungan diplomatik antar negara seperti Indonesia dan Palestina. Indonesia sangat getol membantu kemerdekaan Palestina dikarenakan karena Palestina adalah negara pertama yang mengakui kemerdekaan Indonesia tahun 1945. Kerjasama-kerjasama lain juga dapat dijadikan contoh, misal Amerika dan Israel sangat dekat karena menggunakan proses persuasi ini.

b. Comitment dan Consistency

Proses ini terjadi melalui keyakinan, ide, dan sikap yang diterima oleh penerima pesan dalam meneguhkan keyakinannya sendiri. Misal individu yang yakin bahwa mobil yang akan dibeli adalah mobil mahal dan mewah, maka individu itu tetap akan membeli mobil itu karena yakin akan kualitas mobil itu.

c. Social Proof

Proses ini meyakinkan bahwa lingkungan menjadi episentrum bagi orang-orang disekitarnya untuk 
mengikuti lingkungan yang dianggap menjadi magnet. Misalnya, ketika ada seorang pedagang yang dikerumuni orang banyak, maka persepsi yang terbangun adalah pedagang itu laris dan makanan yang dijual memiliki rasa yang enak. Hal itu yang membuat orang-orang lain mengikuti orang lain untuk membeli makanan dari pedagang itu.

\section{d. Authority}

Proses ini kaitannya dengan kepatuhan terhadap figur yang memiliki pengaruh. Otoritas yang dilakukan dengan persuasi ini banyak dilakukan oleh para psikolog sosial bernama Stanley Milgram, tentang eskperimen sosial tema kepatuhan.

e. Liking

Proses persuasi ini menggunakan sosok individu yang memiliki penampilan menarik walaupun individu tersebut bukan sososk figur yang memiliki posisi tinggi. Individu itu cukup memiliki penampilan yang menarik saja, maka proses persuasi akan dengan sendirinya berjalan. Hal ini dapat dilihat pada pemasaran produk-produk seperti iklan rokok, mobil, atau peralatan rumah tangga. Individu yang bertugas melakukan pemasaran itu tentu harus memiliki penampilan menarik dan memiliki postur yang bagus. $\mathrm{Hal}$ itu akan menarik pembeli untuk membeli dagangan tersebut. Hal yang sama dapat terjadi di maskapai penerbangan, yaitu para pramugari yang melayani para penumpang dengan karakteristiknya sendiri. Pramugari merupakan garda terdepan untuk 
meningkatkan brand dari maskapai yang bersangkutan.

\section{Faktor Pesan dalam Komunikasi Persuasif}

Pesan (message) merupakan sesuatu yang penting dalam konteks komunikasi persuasif. Pesan yang disampaikan oleh komunikator berupa pesan verbal mamupun nonverbal tentu harus dipahami dengan jelas oleh komunikan dengan baik. Terdapat faktor-faktor yang membuat pesan sangat efektif untuk membuat komunikasi persuasif berjalan dengan lancar.

a. Bahasa dan makna dalam komunikasi persuasif, yaitu proses penyampaian yang disertai dengan makna yang mendalam. Komunikator tentu memiliki maknamakna yang tersirat dari apa yang disampaikan melalui bahasa verbal dan nonverbal.

b. Isi pesan persuasif, menekankan adanya pembentukan tanggapan, memperkuat tanggapan, dan mengubah tanggapan. Proses seperti komunikator memperkuat nilai-nilai serta gagasan yang telah tertanam di masyarakat sehingga masyarakt lebih percaya.

c. Efek komunikasi tatap muka sebagai saluran dalam komunikasi persuasi. Proses ini menggunakan media sebagai saluran yang utama dalam melakukan proses komunikasi tatap muka. Saluran yang digunakan untuk tatap muka memiliki beberapa dimensi seperti kredibilitas saluran, umpan balik saluran (feedback), keterlibatan saluran, tersedianya saluran, daya tahan 
saluran, kekuatan multiguna saluran, dan komplementar saluran.

d. Efek interaksi kelompok sebagai saluran dalam komunikasi persuasif

e. Penerima dan pengaruh komunikasi persuasi

\section{Ranah Komunikasi Persuasif}

Persuasi sering kali digunakan dalam berbagai macam ranah atau bidang seperti berikut ini :

1. Bidang politik. Bidang ini dapat dilihat banyaknya politisi menggunakan teknik persuasi untuk menggaet massa saat kampanye. Politisi memang harus punya teknik komunikasi persuasi yang baik.

2. Bidang manajemen. Meliputi manajemen sumber daya manusia atau keuangan. Para pelaku persuasi ini dapat berada di perusahaan yang melakukan semacam persuasi berupa ajakan dan motivasi agar para karyawan dapat bekerja dengan masksimal dan meningkatkan produktifitas kerja. Teknik ini biasanya dilakukan oleh para pejabat perusahaan.

3. Bidang marketing. Bidang ini biasanya digunakan untuk menggaet para konsumen agar datang membeli produkproduk yang telah dijual. Para pengusaha memang memiliki teknik persuasi yang mumpuni untuk melancarkan program-program bisnisnya dan membentuk jaringan yang luas.

4. Bidang hukum. Bidang ini biasanya dilakukan untuk mempengaruhi keputusan para hakim dalam membuat sebuah keputusan perkara. Pengacara biasanya 
melakukan hal ini saat di persidangan untuk meyakinkan kliennya agar klien dapat diselamatkan dalam sebuah perkara.

5. Bidang psikologi. Bidang ini digunakan oleh para psikolog untuk melakukan penyembuhan melalui terapi atau yang biasa dikenal dengan komunikasi therapeutic. Psikolog harus memiliki persuasi yang tepat dan baik untuk menyelasikan permasalahan klien, meyakinkan klien, hingga tahap penyembuhan klien. Pendelatan yang dilakukan dalam komunikasi persuasi adalah pendekatan psikologis yang mencakup tiga fungsi, yaitu control function, cunsomer function, dan knowledge function.

\section{E. Teknik-Teknik Komunikasi Persuasi}

Komunikasi persuasi merupakan sebuah teknik yang harus digunakan oleh semua individu terutama individu yang berada di beberapa ranah di atas. Komunikasi persuasi merupakan sebuah teknik, maka setiap individu yang bertindak sebagai komunikator harus memiliki beberapa teknik dalam melakukan komunikasi persuasi seperti berikut ini :

1. Mampu berpikir dalam kerangka acuan yang lebih besar untuk penggunaan teknik yang tepat dalam suatu keadaan tertentu.

2. Mampu menegakkan kredibilitas.

3. Mampu berempati.

4. Mampu menunjukkan perbedaan dengan sasaran.

5. Mampu mengetahui saat-saat yang tepat untuk dapat menggiring audiensi pada pesan yang diberikan. 
6. Mampu mengetahui alat bantu komunikasi digunakan secara baik dan tepat.

Persuasi juga dapat dikatakan komunikasi yang menggunakan simbol-simbol sebagai alat bantu untuk merubah sikap dan perilaku pada individu. Severin dan Tankard (1992) mengemukakan tiga teknik persuasi yaitu, appeals to humor, appeals to sex, dan extensive repetition of an advertising massage. Tiga teknik persuasi itu merupakan teknik untuk merubah sikap dan perilaku pada individu dengan cara berbagai macam metode seperti humor, seks, dan pesan yang yang dilakukan berulang-ulang dengan tujuan humor. Acara-acara seperti komedi yang dilakukan di tayangan televisi merupakan komunikasi verbal untuk mengubah sikap, perilaku, keyakinan akan penonton terhadap pemain komedi. Pemain komedi memiliki tujuan dan strategi di balik layar untuk memuaskan penonton sekaligus meyakinkan penonton secara aspek kognitif dan emosional agar penonton yakin dari cara bersikap dan berperilaku bahwa pemain komedi tersebut pemain komedi yang handal dan terbaik serta dapat diterima oleh penonton. Politisi yang sedang berkampanye terhadap pendukungnya tentu memiliki strategi dan tujuan yang besar dalam menarik pendukungnya supaya dapat memilihnya. Proses kampanye terkadang bukan hanya sekedar dapat menarik dukungan saja, tetapi ada misi lebih dari sekedar menarik dukungan. Hal ini yang pada akhirnya membuat para komunikator sangat berhati-hati dalam menetapkan strategi dan tujuan sebelum melakukan proses persuasi. Proses persuasi tentu memiliki tujuan yang jelas, oleh karena itu komunikator yang melakukan persuasi 
tentu memiliki strategi yang jelas supaya tujuan yang menjadi target dapat dicapai.

Komunikator yang melakukan persuasi harus memperhatikan hal-hal seperti berikut:

1. Spesifikasi tujuan persuasi. Komunikator yang melakukan persuasi tentu harus memiliki sebuah tujuan yang jelas dan spesifik. Tujuan itu meliputi perilaku, sikap, dan keyakinan yang akan dirubah.

2. Identifikasi kategori sasaran. Proses persuasi harus dapat dilakukan dengan menetapkan tujuan yang spesifik dan dapat dipisahkan sendiri-sendiri sesuai kebutuhannya.

3. Perumusan strategi persuasi. Komunikator tentu harus mampu melakukan strategi persuasi yang jelas sesuai dengan kebutuhan dari apa yang akan dirubah.

4. Pemilihan metode persuasi yang diterapkan. Metode merupakann bagian dari strategi yang sudah dirumuskan. Metode merupakan cara dari komunikator untuk melakukan eksekusi dari yang sudah direncanakan di awal.

\section{RINGKASAN}

1. Komunikasi persuasi merupakan jenis komunikasi yang sering digunakan oleh banyak orang untuk menyelesaikan masalah. Komunikasi persuasif ini digunakan komunikator untuk dapat mempengaruhi komunikan dari segi persepsi, sikap, dan perilaku.

2. Komunikasi persuasif biasanya sering digunakan dalam bidang manajemen, marketing, politik, hukum, dan psikologi. Pada bidang psikologi, komunikasi ini sering 
digunakan dalam proses terapeutic, yaitu proses penyembuhan psikolog terhadap kliennya.

3. Pada strategi persuasif, komunikator harus memperhatikan beberapa hal agar proses persuasi berhasil, yaitu adanya spesifikasi tujuan persuasi, metode persuasi, perumusan startegi komunikasi, dan identifikasi dari tujuan persuasi.

4. Keberhasilan komunikasi persuasive ditentukan oleh komunikator, komunikan, dan pesan yang disampaikan.

\section{LATIHAN}

1. Komunikasi persuasif mampu mempengaruhi komunikan, baik dari segi kognitif, afektif, maupun perilaku. Jelaskan bagaimana proses komunikasi persuasif tersebut!

2. Amati video komunikasi persuasif dengan setting bebas (pendidikan, politik, olahraga, dan lain-lain). Jelaskan faktor-faktor apa saja yang mampu mempengaruhi keberhasilan komunikasi persuasif tersebut (dari segi komunikator, komunikan, dan pesan)!

\section{DAFTAR PUSTAKA}

Burgon \& Huffner. (2002). Human Communication. London: Sage Publication

Seiter, J.S, Weger, H.,Jr dkk ( 2010). “ Nonsmoker's Perception of Male and Female Cigarette Smokers' Credibility, Likeability, Attractiveness, Considerateness, Cleanliness, and Healthiness". Communication Research Reports, 27 (2), 147-158 
Severin, W.J \& Tankard, J.W. (1992). Communication Theoaries: Origins, Methods, and Uses in the Mass Media. New York: Longman

Solihat, I. (2017). " Strategi Komunikasi Persuasif Pengurus Gerakan Pemuda Hijrah dalam Berdakwah".Fakultas Ilmu dakwah dan Ilmu Komunikasi UIN Syarif Hidayatullah, 2017. 


\section{DAFTAR PUSTAKA}

Bara, Bruno G. 2010. Cognitive Pragmatics : The Mental Process of Communication. New York : Massachusetts Institute of Technology.

Barlund, D.C \& F. Halman. (1960). The Dynamics of Discussion, Boston: Houghton-Mifflin .

Baron, R.A., dan Byrne, D., 2003. Psikologi Sosial Jilid 1. Edisi Kesepuluh. Erlangga, Jakarta.

Brehm, S.S., dan Kassin, S.M., 1996. Social Psychology. Third Edition. Prentice-Hall, London.

Burgon \& Huffner. (2002). Human Communication. London: Sage Publication.

Coon, Dennis. 1977. Introduction to Psychology : Exploration and Application. West Publishing Company, College \& School Division.

Dayakisni, T., dan Hudaniah, 2003. Psikologi Sosial. Edisi Revisi. UMM Press, Malang.

Delamater, J. 2006. Handbook of Social Psychology. New York : Springer.

Delamater, John D. dan Myers, Daniel J. 2011. Social Psychology Seventh Edition. Wadsworth Cengage Learning, USA

Fisher, B.A. 1978. Perspectives on Human Communication. New York : Macmillan Publishing Co.,Inc.

Harris, Richard Jackson. 2004. A Cognitive Psychology Of Mass Communication, $4^{\text {th }}$ Edition. New Jersey : Lawrence Erlbaum Associates. 
Hovland, Carl I., Janis, Irving L., Kelley, Harold H. 1953. Communication and Persuasion : Psychological Studies of Opinion Change. New Haven : Yale University Press. Kartz, E., J.G. Blumler \& M. Gurevitch. (1974). " Utilization of Mass Communication by Individual", The Uses of Mass Communication Correct Perspective on Gratification Research, J.G. Blumerand E. Katz, editors, London, Beverly Hills : Sage Publication.

Kassin, S., Fein, S., dan Markus, H.R., 2008. Social Psychology. $7^{\text {th }}$ Edition. Houghton Mifflin Company, New York.

Kenrick, D.T., Neuberg, S.L., dan Cialdini, R.B. 2002. Social Psychology : Unravelling The Mystery. Second Edition. Allyn and Bacon Inc.,Boston.

Klapper, J.T. (1960). The Effects of Mass Communication, Illinois: free Press.

Krauss, Robert M. The Psychology of Verbal Communication. Diakses tanggal 20 Januari 2020.

Kenrick, D.T., Neuberg, S.L., dan Cialdini, R.B. 2002. Social Psychology : Unravelling The Mystery. Second Edition. Allyn and Bacon Inc.,Boston.

King, Laura A. 2012. Psikologi Umum, Sebuah Pandangan Apresiasif, Buku 1. Terjemahan. Jakarta : Salemba Humanika.

King, Laura A. 2012. Psikologi Umum, Sebuah Pandangan Apresiasif, Buku 2. Terjemahan. Jakarta : Salemba Humanika.

Maulana, Herdiyan dan Gumelar, Gumgum. 2013. Psikologi Komunikasi dan Persuasi. Jakarta : Akademia Permata. 
Maryam, Effy W. 2018. Buku Ajar Psikologi Sosial. Sidoarjo : UMSIDA Press.

Maryam, Effy W. 2019. Buku Ajar Psikologi Sosial "Psikologi Sosial : Penerapan dalam Permasalahan Sosial". Sidoarjo : UMSIDA Press.

Myers, D.G. 2004. Theories of Emotion. Seventh Edition. New York : Worth Publishers.

O'connel, Daniel C dan Kowal, Sabine. Communicating With

One Another, Toward a Psychology of Spontaneous Spoken Discourse. New York : Springer.

Oskamp, Stuart. 1998. Applied Social Psychology. $2^{\text {nd }}$ Edition.

Prentice Hall.

Rakhmat, Jalaluddin. 2011. Psikologi Komunikasi, Cetakan Ke-

27. Bandung : Remaja Rosdakarya.

Riggio, Ronald E dan Feldman, Robert S. 2005. Applications of Nonverbal Communication. New Jersey : Lawrence Erlbaum Associates.

Sears, D.O., Freedman, J.L., dan Peplau, L.A., 1985. Social Psychology, Fifth Edition. Toronto : Prentice-Hall, Inc.

Seiter, J.S, Weger, H.,Jr dkk ( 2010). “ Nonsmoker's Perception of Male and Female Cigarette Smokers' Credibility, Likeability, Attractiveness, Considerateness, Cleanliness, and Healthiness". Communication Research Reports, 27 (2), 147-158

Severin, W.J \& Tankard, J.W. (1992). Communication Theoaries: Origins, Methods, and Uses in the Mass Media. New York: Longman

Solihat, I. (2017). " Strategi Komunikasi Persuasif Pengurus Gerakan Pemuda Hijrah dalam Berdakwah".Fakultas 
IImu dakwah dan IImu Komunikasi UIN Syarif Hidayatullah, 2017.

Suryanto, Putra, M.G.B.A., Herdiana, I., dan Alfian, I.N., 2012.

Pengantar Psikologi Sosial. Airlangga University Press, Surabaya.

Tubbs, S.L. dan Moss, Sylvia. 1974. Human Communication : An Interpersonal Perspective. New York : Random House. 


\section{DAFTAR PUSTAKA}

Bara, Bruno G. 2010. Cognitive Pragmatics : The Mental Process of Communication. New York : Massachusetts Institute of Technology

Baron, R.A., dan Byrne, D., 2003. Psikologi Sosial Jilid 1. Edisi Kesepuluh. Erlangga, Jakarta.

Brehm, S.S., dan Kassin, S.M., 1996. Social Psychology. Third Edition. Prentice-Hall, London.

Coon, Dennis. 1977. Introduction to Psychology : Exploration and Application. West Publishing Company, College \& School Division.

Dayakisni, T., dan Hudaniah, 2003. Psikologi Sosial. Edisi Revisi. UMM Press, Malang.

Delamater, J. 2006. Handbook of Social Psychology. New York : Springer.

Fisher, B.A. 1978. Perspectives on Human Communication. New York : Macmillan Publishing Co.,Inc.

Harris, Richard Jackson. 2004. A Cognitive Psychology Of Mass Communication, $4^{\text {th }}$ Edition. New Jersey : Lawrence Erlbaum Associates. 
Hovland, Carl I., Janis, Irving L., Kelley, Harold H. 1953. Communication and Persuasion : Psychological Studies of Opinion Change. New Haven : Yale University Press.

Kassin, S., Fein, S., dan Markus, H.R., 2008. Social Psychology. $7^{\text {th }}$ Edition. Houghton Mifflin Company, New York.

Kenrick, D.T., Neuberg, S.L., dan Cialdini, R.B. 2002. Social Psychology : Unravelling The Mystery. Second Edition. Allyn and Bacon Inc.,Boston.

Krauss, Robert M. The Psychology of Verbal Communication. Diakses tanggal 20 Januari 2020.

Kenrick, D.T., Neuberg, S.L., dan Cialdini, R.B. 2002. Social Psychology : Unravelling The Mystery. Second Edition. Allyn and Bacon Inc.,Boston.

King, Laura A. 2012. Psikologi Umum, Sebuah Pandangan Apresiasif, Buku 1. Terjemahan. Jakarta : Salemba Humanika.

King, Laura A. 2012. Psikologi Umum, Sebuah Pandangan Apresiasif, Buku 2. Terjemahan. Jakarta : Salemba Humanika.

Maulana, Herdiyan dan Gumelar, Gumgum. 2013. Psikologi Komunikasi dan Persuasi. Jakarta : Akademia Permata. 
Maryam, Effy W. 2018. Buku Ajar Psikologi Sosial. Sidoarjo : UMSIDA Press.

Maryam, Effy W. 2019. Buku Ajar Psikologi Sosial "Psikologi Sosial : Penerapan dalam Permasalahan Sosial". Sidoarjo : UMSIDA Press.

Myers, D.G. 2004. Theories of Emotion. Seventh Edition. New York: Worth Publishers.

O'connel, Daniel C dan Kowal, Sabine. Communicating With One Another, Toward a Psychology of Spontaneous Spoken Discourse. New York : Springer.

Oskamp, Stuart. 1998. Applied Social Psychology. $2^{\text {nd }}$ Edition. Prentice Hall.

Rakhmat, Jalaluddin. 2011. Psikologi Komunikasi, Cetakan Ke27. Bandung : Remaja Rosdakarya.

Riggio, Ronald E dan Feldman, Robert S. 2005. Applications of Nonverbal Communication. New Jersey : Lawrence Erlbaum Associates.

Sears, D.O., Freedman, J.L., dan Peplau, L.A., 1985. Social Psychology, Fifth Edition. Toronto : Prentice-Hall, Inc. 
Suryanto, Putra, M.G.B.A., Herdiana, I., dan Alfian, I.N., 2012. Pengantar Psikologi Sosial. Airlangga University Press, Surabaya.

Tubbs, S.L. dan Moss, Sylvia. 1974. Human Communication : An Interpersonal Perspective. New York : Random House. 


\section{BIODATA PENULIS}

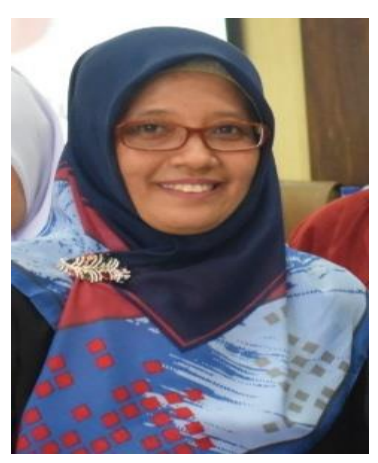

Effy Wardati Maryam, S.Psi.,M.Si., lahir di Sidoarjo pada tanggal 16 Oktober 1976. Pendidikan S1 Psikologi ditempuh di Universitas Muhammadiyah Malang (UMM) dan lulus pada tahun 1999, dilanjutkan dengan menempuh pendidikan S2 Magister Sains Psikologi dengan peminatan Psikologi Komunitas dan Pembangunan di Universitas Airlangga Surabaya lulus pada tahun 2012. Sejak tahun 2005 hingga saat ini aktif sebagai Dosen PNS dpk di Fakultas Psikologi Universitas Muhammadiyah Sidoarjo (UMSIDA). Bidang keahlian yang ditekuni adalah Psikologi Sosial. Fokus kajian dan penelitian yang dikembangkan penulis terkait pemberdayaan masyarakat, modal sosial, sense of community, dan kemiskinan. Buku yang sudah ditulis yaitu Buku Ajar Psikologi Sosial1 diterbitkan pada tahun 2018danBuku Ajar PsikologiSosial 2 "PenerapandalamPermasalahanSosial" yang diterbitkanpadatahun 2019. 


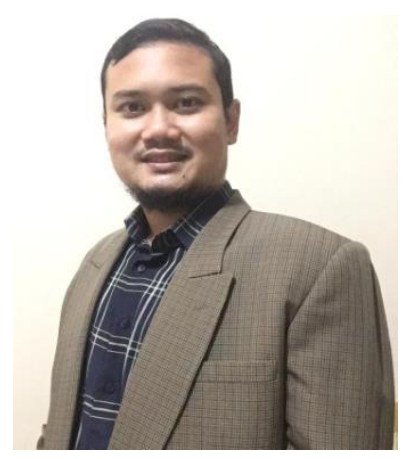

Ramon Ananda paryontri, S.Psi., M.Psi. Penulis adalah dosen Prodi Psikologi Fakultas Psikologi dan Ilmu Pendidikan Universitas Muhammadiyah Sidoarjo (UMSIDA) sejak tahun 2018. Penulis menyelesaikan pendidikan S1 Psikologi di Universitas Gadjah Mada, dan melanjutkan pendidikan S2 di bidang Psikologi Sosial di Fakultas Psikologi Universitas Ahmad Dahlan. Penulis merintis karya ilmiah sejak S1 dan diteruskan di S2 dengan banyak menulis tentang permasalahan sosial dan religiusitas dalam konteks sosial. Penelitian yang telah diterbitkan adalah tentang kepribadian dan kepemimpian Muslim pada tahun 2015 di jurnal Universitas Islam Indonesia. Penulis juga merupakan trainer sekolah dan beberapa perusahaan dengan fokus pada kajian tentang kepemimpinan dan kohesivitas kelompok.Email: ramon_ananda@yahoo.com 